\title{
The change of the Spanish tourist model: from the sun and sand to the security and sand
}

\begin{tabular}{|r|l|}
\hline Journal: & Tourism Economics \\
\hline Manuscript ID & TEU-19-0386.R1 \\
\hline Keywords: & Spain, Meta-frontier, DEA, Tourism efficiency, Regional tourism \\
\hline Abstract: & $\begin{array}{l}\text { There is evidence of specialization in tourism destinations, but also a lack } \\
\text { of literature regarding its impact on tourism regional performance. This } \\
\text { study aims to contribute to the analysis of the determinants of tourism } \\
\text { performance. To this end, the efficiency of 17 Spanish regions has been } \\
\text { estimated by meta-frontier DEA techniques over the 2008-2018 period. } \\
\text { In the second stage, we adopt the bootstrapping method proposed by } \\
\text { Simar and Wilson (2007) to measure the impact of explanatory factors } \\
\text { on tourism efficiency. } \\
\text { The results suggest that regions specialized in tourism may achieve } \\
\text { higher efficiency levels. However, there is evidence of a catching-up } \\
\text { process in the tourism technology of the Spanish regions over the last } \\
\text { ten years. Results also suggest that sand (kilometers of beaches) and } \\
\text { insecurity are the key drivers of tourism efficiency. Furthermore, natural } \\
\text { attractions factor that most positively influences efficiency in non- } \\
\text { specialized regions. }\end{array}$ \\
\hline
\end{tabular}

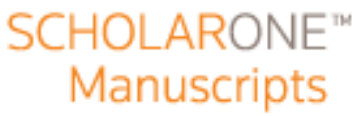




\title{
The change of the Spanish tourist model: from the Sun and Sand to the Security and Sand
}

\begin{abstract}
There is evidence of specialisation in tourism destinations, but also a lack of literature regarding its impact on tourism regional performance. This study aims to contribute to the analysis of the determinants of tourism performance. To this end, the efficiency of 17 Spanish regions has been estimated by meta-frontier DEA techniques over the 2008-2018 period. In the second stage, we adopt the bootstrapping method proposed by Simar and Wilson (2007) to measure the impact of explanatory factors on tourism efficiency.

The results suggest that regions specialised in tourism may achieve higher efficiency levels. However, there is evidence of a catching-up process in the tourism technology of the Spanish regions over the last ten years. Results also suggest that sand (kilometres of beaches) and insecurity are the key drivers of tourism efficiency. Furthermore, natural attractions factor that most positively influences efficiency in non-specialised regions.
\end{abstract}

Keywords: Spain, Meta-frontier, DEA, Tourism efficiency, Regional tourism.

\section{Introduction}

Tourism is a real global force for economic growth and development. By serving as a catalyst for innovation and entrepreneurship and creating more and better jobs, it helps 
to build better lives for millions of individuals (UNWTO, 2019). According to the World Travel and Tourism Council (WTTC, 2019), tourism contributes 3.2\% (\$2,750.7 billion) to the global GDP and supports one in every ten jobs in the world, generating $3.8 \%$ of the total employment in 2018.

Despite the downside risks (economic slowdown, Brexit uncertainty etc.), the number of international travellers is still increasing worldwide (UNWTO, 2019). For years, the most popular part of the world is the European Union (EU), concentrating $39.15 \%$ of global tourism over the past decade (World Bank, 2019). The EU attracts foreign tourists by their agreeable warm climate throughout the year with rich historical culture and extensive sandy beaches.

In this sense, Spain is one of the major tourist powers, receiving $5.20 \%$ of all international tourists from all around the world over the last twenty years(World Bank, 2019). Spain has a suitable environment for natural, cultural and both sand and sea and ski tourism in most regions, due to its historical endowment and geographical situation (orographic conditions) with the Mediterranean, the semi-arid and oceanic climate. According to the Tourist Movement on Borders (Frontur, 2019), Spain received 81,786,364 international tourists in 2018.

Spain is often shown to be at the top of the list of countries with the most productive international tourism. Despite this, it is relevant to evaluate whether are differences among the efficiency of regional tourism (from now on RT) in Spain. RT means a geographical location (region) where natural and human-made environment, supplied by private and public agents, are organised and managed to attract tourists and be enjoyed by them (Botti et al., 2009; Barros et al., 2011).

This study aims to contribute to the analysis of the determinants of tourism performance. The evaluation of the drivers of tourism performance is especially relevant, due to the importance of the tourism sector in the Spanish regional economy.

To address the research aims, a two-stage procedure is applied. First, we carry out a meta-frontier DEA to obtain the efficiency scores. Then, we use the bootstrapping method 
proposed by Simar and Wilson (2007) to measure the impact of explanatory factors on the tourism efficiency of the Spanish regions. This research presents the following novelties: (1) efficiency evaluation is carried out separately by grouping regions in accordance with their tourism specialization (Non-tourist: Pais Vasco, Cantabria, Asturias, Aragon, Galicia, Rioja, Castilla - Leon, Navarra, Castilla - La Mancha, Extremadura; Tourist specialization: Balears Illes, Canarias, Comunitat Valenciana, Cataluna, Madrid, Murcia, Andalucia), which allows dealing with regional heterogeneity in the DEA estimation. (2) Efficiency determinants are evaluated separately for the two groups of regions, which enables us to see whether the impact of factors determining performance depends on the tourist orientation of the regions.

The article is organized as follows. In section 4.2., we review the literature on previous studies on the efficiency of RTs. Section 4.3. presents an empirical model for estimation. Section 4.4. describes the data and descriptive statistics of the variables used. Section 4.5. illustrates the results and section 4.6. highlights the conclusion of the research.

\section{Literature review}

Tourism stimulates economic research to investigate ways to use it as a driver of economic growth due to its industrial relevance. There is an increasing interest in assessing the efficiency of tourism sub-sectors (hotel, restaurant, service, tourist transportation, etc.) and the effectiveness of public policy for increasing the efficiency of RT. Various frontier models are used, from nonparametric to parametric and stochastic methods. Among the various frontier approaches the most used are two different methodologies: the parametric method, Stochastic Frontier Analysis (SFA) (Aigner et al., 1977) and the non-parametric method, Data Envelopment Analysis (DEA) (Charnes et al., 1978). The advantage of these frontier methods over regression, partial and simple productivity techniques lies in the calculation of efficiency based on the concept proposed by Farrell (1957). According to this concept, productivity is defined as the ratio of input to output and can be calculated using a single or by aggregating multiple inputs and outputs.

In the frontier methods, the criterion in comparing the efficiency of a Decision-making unit (DMUs) is assessing the distance of each DMU from the frontier. Thus, focusing on RT 
efficiency, the frontier is used as the basis for comparison between different DMUs. Nevertheless, many researchers ignore the fact that if the DMUs under study operate under different characteristics, it becomes inaccessible to use a single frontier in comparing the efficiency of the various firms (Matawie and Assaf, 2008). Such problems mainly occur when comparisons between DMUs from different groups are inaccessible. To solve this, referring to the concept of Meta-frontier proposed by Hayami (1969), and Hayami and Ruttan (1970), later Battese and Rao (2002), Battese et al. (2004) and O'Donnell et al. (2008) have addressed the issue of a single frontier when group differences exist between the different firms. An advantage of this model is that it allows for the investigation of DMUs' efficiency in different groups that operate under different characteristics. Therefore, the Meta-frontier model is considered as an envelope of all the possible group frontiers.

The approach proposed by O'Donnell et al. (2008) shows that the meta technical inefficiency under the Meta-frontier can not only be divided into two parts (technology gap inefficiency and group technical inefficiency) but also can be used to justify the direction for improvement of technology. Since the development of the Meta-frontier DEA model (O'Donnell et al., 2008) coming out, various Meta-frontier approaches based on DEA have been proposed (Assaf and Matawie (2010), Sala-Garrido et al. (2011), Tiedemann et al. (2011), Chiu et al. (2013). Table 1. shows the DEA oriented Meta-frontier approach timetable.

Table 1: DEA oriented Meta-frontier approach timetable

Likewise, since every additional update, a growing number of studies have applied various meta-frontier DEA models to measure the group efficiency, meta-efficiency and technology gap in multiple industries (Medal-Bartual et al., 2012, Wang et al., 2014 Molinos-Senante et al., 2015, Chen et al., 2017, among others). 
Regarding the analysis of tourist efficiency, the literature has analysed tourism efficiency worldwide (Assaf and Josiassen, 2012; Hadad et al., 2012), in Europe (Abad and Kongmanwatana, 2015; Lozano and Gutiérrez, 2011; Soysal-Kurt 2017) and at regional level in Italy (Bosetti et al., 2004; Bosetti et al., 2007; Cuccia et al., 2016), France (Peypoch, 2007, Botti et al., 2009, Barros et al., 2011), Spain (Benito et al., 2014, Martin et al., 2017) among others.

In terms of applications in the tourism industry, most studies which use the Meta-frontier approach evaluate hotel performance, such as Assaf et al. (2010), Huang et al. (2013), Lin et al., (2012), Yu and Chen (2019), Cho and Wang (2018), Lu and Chen (2012), Yu and Chen (2019). Also, restaurants are assessed by Fang and Hsu (2012), Fang et al. (2013), Fang and Hsu (2014), Alberca and Parte (2018). In regional tourism (Benito et al., 2014; Cuccia et al., 2017; Assaf and Josiassen (2016); Assaf and Dwyer (2013); Zha et al., 2019).

Despite the increasing number of papers using various types of Meta-frontier approaches, the method is relatively novel in operation research (OR), and in the literature, as far as we found, there are still no studies on Spanish RT that use The Meta-frontier DEA approach.

\section{Theoretical and empirical Model}

The efficiency of RT has been analysed using different approaches such as regression analysis, productivity index, and ratio analysis. However, the frontier analysis is by far the most used approach. Frontier analysis can be applied using two different methodologies: parametric methods, such as the Stochastic Frontier Analysis (SFA) and non-parametric methods such as Data Envelopment Analysis (DEA). At the first stage of papers' analysis, we use DEA for implementing the non-concave Meta-frontier as DEA is suited to measure efficiencies of deterministic industry for multiple inputs/outputs sets (Lam et al., 2009).

\section{Data envelopment analysis}


DEA is a non-parametric methodology introduced by Charnes et al. (1978). Based on linear programming, it is used to measure the relative performance of a set of similar organisational units (DMUs) by using multiple measures of inputs and outputs. The DEA model determines the efficiency score for each DMU, obtained as a ratio of weighted outputs to weighted inputs.

Formally, since a total of $L=\sum_{k} L_{k}$ regions, the input-oriented technical efficiency under constant return to scale (CRS) is obtained by solving the following linear programming problem:

$$
\begin{gathered}
\min _{\theta_{i t}, \lambda_{i t}} \theta_{i t} \\
\text { s.t. } \theta_{i t} x_{i t}-\lambda_{i t} X \geq 0, \\
-y_{i t}+\lambda_{i t} Y \geq 0 \\
\lambda_{i t} \geq 0
\end{gathered}
$$

where $y_{i t}$ is the $M x 1$ vector of output quantity for the $i$ th region in the $t$ th period, $x_{i t}$ is the $M x 1$ vector of input quantities for the $i$ th region in the $t$ th period; $Y$ is the $M x L$ matrix of output quantities for all $L$ regions; $X$ is the $M x L$ matrix of input quantities for all $L$ regions; $\lambda_{i t}$ is an $L x 1$ non-negative vector of weights; and $\theta_{i t}$ depicts a scalar. Thus, $1 / \theta_{i t}$ is an estimate of the overall technical efficiency (OTE) of $i$ th region in the $t$ th period under CRS. By adding the constraint of convexity on the model (Variables Returns to Scale), one can find the technical efficiency arising from optimal management practices, called pure technical efficiency (PTE) (Banker et al., 1984). Finally, the technical efficiency due to optimal or suboptimal production scale, scale efficiency (SE) can be obtained by the ratio between OTE and PTE (Coelli et al., 2005).

\section{The Meta-frontier model}

On a theoretical basis, the organizational units (DMUs) participating in the same frontier employ the same set of inputs and share the same technology set. Thus, the DEA discriminatory power is dependent on the homogeneity of the domain of the sample (Samoilenko and Osei-Bryson, 2008). However, as discussed in section 4.2., the Spanish 
RT have different touristic technologies, management levels, and therefore different production frontiers. To take into account the differences in technology across the Spanish RT, this paper proposes the meta-frontier approach. Based on the metaproduction function introduced by Hayami (1969), and Ruttan and Hayami (1970), this technique aims to provide a homogenous boundary for all heterogeneous DMUs by estimating the frontiers of relatively homogenous groups (Battese and Rao., 2002; Battese et al., 2004; O'Donnell et al., 2008). Finally, a new production frontier (called metatechnology) is obtained through enveloping the boundaries of different groups.

Formally, let $x$ and $y$ denote the (non-negative) input and output vectors of dimensions ( $M x 1)$ and $(N x 1)$. We assume that production technology is the knowledge and ability to transform inputs into outputs. We consider $K(>1)$ specific technology groups, $T^{K}$. The production technology $\left(T^{k}\right)$ of the $k$ th group, with $k=1,2,3, \ldots K$, is given by:

$$
T^{k}=\left\{\left(x^{k}, y^{k}\right) \in R^{+} \mid x^{k} \text { canproduce } y^{k}\right\}
$$

The production technology set $T^{k}$, provides an equivalent representation of the capability of transforming inputs into outputs. The group-specific input set $\left(X^{k}\right)$ defined for a specific output vector $y^{k}$ is defined as:

$$
X^{k}\left(y^{k}\right)=\left\{x^{k}:\left(x^{k}, y^{k}\right) \in T^{k}\right\}
$$

The boundaries of the input sets determine the 'isoquants'. The group-specific output set $\left(P^{k}\right)$ is defined for a specific vector of input $x^{k}$ as:

$$
P^{k}\left(x^{k}\right)=\left\{y^{k}:\left(x^{k}, y^{k}\right) \in T^{k}\right\}
$$


The technology set for the $k$ th group can be represented by the following distance function based on input minimisation:

$$
D_{i}^{k}\left(x^{k}, y^{k}\right)=\sup _{\lambda}\left\{\lambda>0:\left(x^{k} / \lambda\right) \in X^{K}\left(y^{k}\right)\right\}
$$

and it shows the ratio of the actual production levels to the frontier production levels. The distance function can be used to measure the technical efficiency of the production unit (Shepard 1962):

$$
0 \leq T E^{k}\left(x^{k}, y^{k}\right)=\left[D_{i}^{k}\left(x^{k}, y^{k}\right)\right]^{-1} \leq 1
$$

As we assume that there is a sub technology collection $T^{k}$ which operates under a standard technical collection, the production technology of the meta-frontier $\left(T^{\text {meta }}\right)$ is given by:

$$
T^{\text {meta }}=\left\{T^{1} \cup T^{2} \cup \ldots \cup T^{k}\right\}=\left\{(x, y) \in R^{+} \mid x c \text { anproducey }\right\}
$$

Since meta-frontier is different from group frontier, the technical gap between the groups can be overcome, and all the production units have the same technical possibilities to pursuit input minimisation (Battese and Rao, 2002). The input-orientated meta-distance function $\left(D_{i}^{\text {meta }}\right)$ can be represented as:

$$
D_{i}^{\text {meta }}(x, y)=\sup _{\lambda}\left\{\lambda>0:(x / \lambda) \in X^{\text {meta }}\left(y^{\text {meta }}\right)\right\}
$$

Finally, the Technical Efficiency based on the common frontier can be expressed as: 


$$
0 \leq T E^{m e t a}(x, y)=\left[D_{i}^{m e t a}(x, y)\right]^{-1} \leq 1
$$

From the definition of the metatechnology it can be easily shown that $D_{i}^{k}\left(x^{k}, y^{k}\right) \leq D_{i}^{\text {meta }}$ $(x, y)$.

A purpose of distinguishing the difference between technologies, we define the technology gap ratio (TGR) of efficiency. Following Battese et al. (2004) and O'Donnell et al. (2008), the technology gap ratio $(T G R)$ is constructed as in Eq. (9). The bigger the technology gap ratio, the closer the group frontier technology to the meta-frontier. If $T G R$ equals 1, no gap exists between the group frontier technology and meta-frontier technology. To illustrate it, the input-orientated TGR can be defined using the input distances functions from technologies $T^{k}$ and $T^{\text {meta }}$ as:

$$
0 \leq T G R_{i}^{k}=\frac{D_{i}^{k}\left(x^{k}, y^{k}\right)}{D_{i}^{\text {meta }}(x, y)}=\frac{T E^{k}\left(x^{k}, y^{k}\right)}{T E^{\text {meta }}(x, y)} \leq 1
$$

The CCR model fits a linear production technology in the meta-frontier, whereas the BCC model features variable returns to scale, which are more flexible and reflect managerial efficiency as well as purely technical limits.

\section{Parametric regression}

To analyse the extent to which efficiency impact of explanatory factors on Spanish tourist and non-tourist regions, we use the two-stage bootstrap truncated regression procedure (Simar and Wilson, 2007).

An advantage of the Simar and Wilson (2007) bootstrap procedure is that it allows obtaining unbiased coefficients, valid confidence intervals and describe a data generating process under which two-step methods are consistent. The basic idea of bootstrapping is the recalculation of the parameter of interest. This is achieved by the approximation of the distribution of the estimator via re-sampling. In this research, the recalculated 
parameter of interest is the DEA efficiency score. Since variables exist to explain the variation in the efficiency scores, the bootstrap procedure can be extended to account for the impact of environmental variables on efficiency (Assaf and Josiassen, 2011). The discriminatory power of the first stage is not affected since the explanatory variables are not included in the first stage (Liebert and Niemeier, 2013).

The mathematical expression of such regression given by:

$$
\varphi_{j}=a+z_{j} \delta+\varepsilon_{j}
$$

Where $a$ is the constant term, $\varepsilon_{j}$ is the error term, $z_{j}$ is a vector (row) of potential covariates that are expected to be related to the DMU's efficiency score, $\varphi$.

\section{The research framework}

The research framework of this study is shown in figure 1. The first stage assesses the efficiency of Spanish regions via DEA (Carner et al., 1978; Banker et al., 1984). The design involves the DEA, which explains technical efficiency (CRS, VRS) and scale efficiency. An advantage of the DEA assessment is that the model can be calculated from different angles and builds a comprehensive analysis with new approaches (Benito et al., 2014). In the second stage, to discover the factors that significantly affect the efficiency in tourist and non-tourist regions in Spain it applies the bootstrapping method proposed by Simar and Wilson (2007).

The Spanish regions form a quite heterogeneous group in terms of size and output composition. Therefore, changes in the environment or technology could not affect all equally. Consequently, to carry out the analysis, regions are grouped by similar characteristic. In this sense, the National Geographical Institute of Spain classifies them in two groups according to their tourism orientation (Fernandez et al. 2018). Group 1 contains regions with the high-density touristic areas (Balears Illes, Canarias, Comunitat Valenciana, Cataluna, Madrid, Murcia, Andalucia) and group 2, regions that do not 
specialize in tourism (Pais Vasco, Cantabria, Asturias, Aragon, Galicia, Rioja, Castilla Leon, Navarra, Castilla - La Mancha, Extremadura).

Figure 1: Framework of this study.

\section{Sources and Data}

To evaluate the RT in Spain, the data for 17 Spanish regions (Ceuta and Melilla are not included) have been collected for the period 2008-2018. For the construction of the input and output variables of the determinants of efficiency, data of the National Statistical Institute (INE) and State Meteorological Agency (AEMET) has been used ${ }^{1}$. To measure the effect of explanatory factors on the efficiency on both Spanish tourist and non-tourist regions, variables need to be logically connected to determine the efficiency. As Lew (1987), Leiper (1990), Barros et al., (2011) and Assaf and Josiassen (2012) indicated the variables selected at this stage include tourism attractors that affect the success of its destination. Thus, to analyse the impact of explanatory factors, four variables were used (z-variables): SUN, SAND, NATURAL ATTRACTIONS, and INSECURITY. Table 2. contains the selection, description and analysis of antecedents of these variables.

Table 2: Variables for the Simar and Wilson (2007) analysis of determinants.

In the first stage of the analysis, the selection of output and input variables have been chosen based on a review of the literature mentioned in section 2., and the data at our disposal. Figure 1 shows the following variables which are used as input variables: Tourists arrivals to Spain measured by the number of tourists arriving to Spain, Tourism employment measured by the number of employees involved in tourism, and Tourism capacity measured by the number of available bedrooms to receive tourists. As output

\footnotetext{
1 Tourist Movement on Borders (FRONTUR), Tourism Expenditure Survey (EGATUR), Hotel Occupancy Survey (HOS), Campsite Occupancy Survey (COS), Labour Force Survey (LFS), Survey of domestic tourism, Tourist Accommodation Occupancy Survey covers, Hostel Occupancy Survey
} 
variables, Tourists spending is measured by the amount of tourists' spending in MLN euros and, Occupancy rate measured by the number of tourists' overnight stays in hosting places. The descriptive statistics of the variables used are shown in table 3 and 4 .

Table 3: Summary statistics of inputs and outputs

Table 4: Summary statistics of variables in averages by regions for 2008-2018

\section{Results}

As mentioned in section 3, the assessment consists of two stages. The DEA approach was used in 17 regions to assess the efficiency levels of the Spanish regions (Ceuta and Melilla are not included) at the first stage over the 2008-2018 period, and the second stage used the parametric regression proposed by Simar and Wilson (2007). In the second stage, the homogeneous smoothing approach with 1000 iteration was applied to solve the potential problem of biased results.

The tourist efficiency results under CRS, VRS and the scale efficiency of the 17 Spanish regions are displayed in table 5 . These scores are relative measures to the most efficient unit $(100 \%)$, ranging between $0-1$, where 0 is inefficient, and 1 is efficient. The results revealed that the average technical efficiency for all regions is 0.70 (CRS), for tourist regions is 0.89 (CRS) and non-tourist regions is 0.56 (CRS). The most efficient regions (score between 0.73 and 1.0) are those with an exit to the seaside, such as Balears Illes, Canarias, Comunitat Valenciana, Cataluña, Madrid (capital), Murcia and Andalucía.

Table 5: The average scores of efficiency of tourist and non-tourist regions in Spain (20082018) ranked overall technical efficiency (CRS), pure technical efficiency (VRS) and scale efficiency. 
Apart from the Canary Islands and Madrid (capital), geographically, all regions are located in the Mediterranean area.

On the other hand, all non-tourist regions are located in the central and northwestern parts of the country. The level of efficiency of non-tourist regions is lower (between 0.46 and 0.69 ) compared with the tourist regions. The highest efficiency score (score between 0.50 and 0.60 ) among the non-tourist regions belongs to Pais Vasco and Cantabria. The lowest efficiency score belongs to Extremadura (under 0.50). All the rest regions (Asturias, Aragon, Galicia, Rioja, Castilla - Leon, Navarra and Castilla - La Mancha) show a score between 0.40 and 0.50 .

As it expected, Spain attracts international tourists with its Sun and Sand type tourism (Aguilo et al., 2005). These results are in line with findings of Munoz (2007), which states that international travellers are concentrated in destinations, such as the Balearic Islands, Canary Islands, Andalusia and Catalonia. The results are also concurrent with the research by Herrero-Prieto and Gomez-Vega, 2017, and Fernández et al., 2018 for airports and cultural festivals.

Table 6. displays the measure of the effect of explanatory factors on the efficiency of both Spanish tourist and non-tourist regions. The analysis results show that the SUN factor negatively affects the efficiency of the tourist $(-0.0105$, CRS; -0.0074, CRS) and nontourist regions $(-0.0018$, CRS; -0.0013 , VRS). The results can be explained by Leibenstein (1966) and its X-inefficiency theory on non-allocative form of efficiency. Sunny regions feel more protected against competition due to favorable environmental conditions. Also, Benito et al., (2014), Munoz (2007), Martin et al., (2017), Hein et al., (2009) support the influence of the sun on incoming visitors.

Table 6: Parameter estimates for the Simar-Wilson regression model of tourist and nontourist regions in Spain (2008-2018). 
The variable SAND has a positive effect on tourist $(0.0002, \mathrm{CRS})$ and non-tourist $(0.0002$, VRS) regions efficiency. In other words, the longer the beaches, the higher the efficiency level of the region. The results are consistent with Benito et al., (2014), who found that nature and beaches have a positive effect on the competitiveness of Spanish autonomous communities. Furthermore, seaside and beaches argues by Barros et al (2011), SellersRubio and Casado-Díaz (2018), Claver-Cortés et al., (2007).

The explanatory factor NATURAL ATTRACTIONS has a significant positive effect on efficiency in non-tourist regions (0.0414, CRS). This effect may be associated with the attractors of these regions. It is essential to have national parks, as most non-tourist regions regarding their geographical and natural environment have no specific attractors as in tourist regions. These results are consistent with those obtained by Cuccia et al. (2017).

Security is an important driver of tourism performance. The explanatory factor INSECURITY has a significant adverse effect on the efficiency of tourist regions (-8.4200, CRS; -1.5500, VRS). The results are in line with Pizam, (1999), Levantis and Gani, (2000), and Santana-Gallego et al., 2016, who too have considered tourist security.

Table 7 shows Technical efficiency $\left(T E^{k}\right)$, Metafrontier efficiency $\left(T E^{\text {meta }}\right)$, and technological gaps (TGR), as indicated in section 4.3. In average, the tourist regions possess the best tourism utilisation technology. The results suggest that they require a smaller amount of input to produce a given set of outputs compared to the non-tourist areas.

Table 7: Technical efficiency $\left(T E^{k}\right)$, Metafrontier efficiency $\left(T E^{m e t a}\right)$ and technological gaps $(T G R)$

There are significant differences in efficiency between the tourist and non-tourist Spanish regions over the last 10 years. Figure 2 . shows the average ratio of the technological gap in the tourist and non-tourist regions of Spain for the period $2008-2018$. 
Figure 2: Evolution of Technology Gap Ratio (TGR) by groups (2008-2018).

As the figure illustrates, tourist regions remain on the meta-frontier throughout the entire period $(T G R=1)$. However, there is a convergence between the tourist and non-tourist regions of Spain.

Non-tourism regions show improvements in their level of efficiency. A visible leap in efficiency gains of non-tourist areas has been seen in 2014 and 2016.

\section{Conclusion}

This article aims to assess the drivers of tourism performance of Spain at the regional level. A Meta-frontier DEA (Carnes et al., 1978; Battese et al., 2004; O'Donnell et al., 2008) was first carried out to obtain the efficiency scores for each region. Secondly, the bootstrapping method (Simar and Wilson, 2007) was applied to measure the impact of explanatory factors on tourist and non-tourist regional efficiency. The following novelties are presented in this study: (1) we take into account the heterogeneity of regions in the DEA estimation. Therefore the efficiency evaluation is carried out separately by grouping the regions by their focus on tourism. (2) We evaluate the factors determining performance depending on the tourist orientation of the regions. The first stage of the analysis shows that geographical location have a significant impact on the efficiency of Spanish RT. The most efficient regions are the capital and the tourist-oriented regions with an exit to the seaside.

Over the past 10 years a convergence in the efficiency level between the tourist and nontourist regions of Spain has been observed. On the whole, tourist regions have the best tourism technology. This result indicates that they need fewer resources to get a given set of outputs.

The analysis of the efficiency effect on RT of the second stage showed that the NATURAL ATTRACTIONS impacts positively on tourism performance of the non-tourist regions and 
the SAND ( $\mathrm{km}$ of beaches) positively affect the efficiency levels of both tourist and nontourist regions.

The drivers of tourism performance, such as the SUN and INSECURITY harm the efficiency of Spanish RT. The SUN factor negatively affects the efficiency of both tourist and non-tourist regions. A possible explanation for these finding may relate to $X$ inefficiency theory on the non-allocative form of efficiency by Leibenstein (1966). Regions with more number of sunny days feel more protected against competition due to the favourable environmental conditions and a large number of inbound tourists. The INSECURITY factor also negatively effects the efficiency of tourist regions.

In general, the main conclusion of this study allows us not only to understand but also to establish what factors are significant in regional performance, thus providing statistically reliable information on the efficiency of Spanish RT. Our findings are useful for both scientists and practitioners who seek to understand the factors that contribute to the efficiency of regional tourism. From this point of view, the results of the study can, above all, be considered as an essential guide for regional authorities to maximise the use of geographical and natural advantages to attract tourists as a source of economic development. 


\section{References}

Abad, A., \& Kongmanwatana, P. (2015). Comparison of destination competitiveness ranking in the European Union using a nonparametric approach. Tourism Economics, 21(2), 267-281.

Aguiló, E., Alegre, J., \& Sard, M. (2005). The persistence of the sun and sand tourism model. Tourism management, 26(2), 219-231.

Aigner, D., Lovell, C. K., \& Schmidt, P. (1977). Formulation and estimation of stochastic frontier production function models. Journal of econometrics, 6(1), 21-37.

Akama, J. S., \& Kieti, D. M. (2003). Measuring tourist satisfaction with Kenya's wildlife safari: a case study of Tsavo West National Park. Tourism management, 24(1), 73-81.

Alberca, P., \& Parte, L. (2018). Operational efficiency evaluation of restaurant firms. International Journal of Contemporary Hospitality Management, 30(3), 1959-1977.

Alegre, J., \& Cladera, M. (2006). Repeat visitation in mature sun and sand holiday destinations. Journal of travel research, 44(3), 288-297.

Assaf, A. G., \& Dwyer, L. (2013). Benchmarking international tourism destinations. Tourism Economics, 19(6), 1233-1247.

Assaf, A. G., \& Josiassen, A. (2011). The operational performance of UK airlines: 20022007. Journal of Economic Studies, 38(1), 5-16.

Assaf, A. G., \& Josiassen, A. (2012). Identifying and Ranking the Determinants of Tourism Performance: A Global Investigation. Journal of Travel Research, 51(4), 388-399.

Assaf, A. G., \& Josiassen, A. (2016). Frontier analysis: A state-of-the-art review and metaanalysis. Journal of Travel Research, 55(5), 612-627. 
Assaf, A., \& Matawie, K. M. (2008). Cost efficiency modeling in health care foodservice operations. International Journal of Hospitality Management, 27(4), 604-613.

Assaf, A., \& Matawie, K. M. (2010). A bootstrapped metafrontier model. Applied Economics Letters, 17(6), 613-617.

Banker, R. D., Charnes, A., \& Cooper, W. W. (1984). Some models for estimating technical and scale inefficiencies in data envelopment analysis. Management science, 30(9), 1078-1092.

Barros, C. P., Botti, L., Peypoch, N., Robinot, E., \& Solonandrasana, B. (2011). Performance of French destinations: Tourism attraction perspectives. Tourism Management, 32(1), 141-146.

Battese, G. E., \& Rao, D. P. (2002). Technology gap, efficiency, and a stochastic metafrontier function. International Journal of Business and Economics, 1(2), 87.

Battese, G. E., Rao, D. P., \& O'donnell, C. J. (2004). A Meta-frontier production function for estimation of technical efficiencies and technology gaps for firms operating under different technologies. Journal of productivity analysis, 21(1), 91-103.

Benito, B., Solana, J., \& López, P. (2014). Determinants of Spanish regions' tourism performance: a two-stage, double-bootstrap data envelopment analysis. Tourism Economics, 20(5), 987-1012.

Bosetti, V., Cassinelli, M., \& Lanza, A. (2004). Using Data Envelopment Analysis to Evaluate Environmentally Conscious Tourism Management. 
Bosetti, V., Cassinelli, M., \& Lanza, A. (2007). Benchmarking in Tourism Destinations; Keeping in Mind the Sustainable Paradigm. Advances in Modern Tourism Research, 165180.

Botti, L., Peypoch, N., Robinot, E., \& Solonadrasana, B. (2009). Tourism destination competitiveness: the French regions case. European Journal of Tourism Research, 2(1), 5 .

Botti, L., Peypoch, N., Robinot, E., \& Solonadrasana, B. (2009). Tourism destination competitiveness: the french regions case. European Journal of Tourism Research, 2(1), $5-24$.

Buultjens, J., \& Luckie, K. (2004). Economic impact of selected national parks in northeastern New South Wales. Gold Coast: CRC for Sustainable Tourism.

Charnes, A., Cooper, W. W., \& Rhodes, E. (1978). Measuring the efficiency of decision making units. European journal of operational research, 2(6), 429-444.

Chen, Y. H., Lai, P. L., \& Piboonrungroj, P. (2017). The relationship between airport performance and privatisation policy: A nonparametric metafrontier approach. Journal of Transport Geography, 62, 229-235.

Chiu, C. R., Chiu, Y. H., Chen, Y. C., \& Fang, C. L. (2016). Exploring the source of metafrontier inefficiency for various bank types in the two-stage network system with undesirable output. Pacific-Basin Finance Journal, 36, 1-13.

Chiu, C. R., Lu, K. H., Tsang, S. S., \& Chen, Y. F. (2013). Decomposition of meta-frontier inefficiency in the two-stage network directional distance function with quasi-fixed inputs. International Transactions in Operational Research, 20(4), 595-611. 
Chiu, Y. H., Luo, Z., Chen, Y. C., Wang, Z., \& Tsai, M. P. (2013). A comparison of operating performance management between Taiwan banks and foreign banks based on the Meta-Hybrid DEA model. Economic Modelling, 33, 433-439.

Cho, T. Y., \& Wang, T. Y. (2018). Estimations of cost metafrontier Malmquist productivity index: using international tourism hotels in Taiwan as an example. Empirical Economics, 55(4), 1661-1694.

Claver-Cortés, E., Molina-Azorı, J. F., \& Pereira-Moliner, J. (2007). Competitiveness in mass tourism. Annals of tourism Research, 34(3), 727-745.

Coelli, T. J., Rao, D. S. P., O'Donnell, C. J., \& Battese, G. E. (2005). An introduction to efficiency and productivity analysis. Springer Science \& Business Media.

Cuccia, T., Guccio, C., \& Rizzo, I. (2016). The effects of UNESCO World Heritage List inscription on tourism destinations performance in Italian regions. Economic Modelling, $53,494-508$.

Cuccia, T., Guccio, C., \& Rizzo, I. (2017). UNESCO sites and performance trend of Italian regional tourism destinations: A two-stage DEA window analysis with spatial interaction. Tourism Economics, 23(2), 316-342.

Fang, C. Y., \& Hsu, F. S. (2012). Meal category analysis: An application of the metafrontier approach. Tourism Economics, 18(5), 1083-1095.

Fang, C. Y., \& Hsu, F. S. (2014). An efficiency-based metafrontier approach to menu analysis. Journal of Hospitality \& Tourism Research, 38(2), 199-221.

Fang, C. Y., Peng, P. Y., \& Pan, W. T. (2013). Does using an à la carte or combo set menu affect the performance of a teppanyaki-style restaurant?. International Journal of Contemporary Hospitality Management, 25(4), 491-509. 
Färe, R., \& Grosskopf, S. (2010). Directional distance functions and slacks-based measures of efficiency. European journal of operational research, 200(1), 320-322.

Farrell, M. J. (1957). The measurement of productive efficiency. Journal of the Royal Statistical Society: Series A (General), 120(3), 253-281.

Fernández, X. L., Coto-Millán, P., \& Díaz-Medina, B. (2018). The impact of tourism on airport efficiency: The Spanish case. Utilities Policy, 55, 52-58.

George, R. (2003). Tourist's perceptions of safety and security while visiting Cape Town. Tourism Management, 24(5), 575-585.

GISBERT, J. I., PALAZÓN, A., LÓPEZ, I., ARAGONÉS, L., \& VILLACAMPA, Y. (2018). STUDY OF THE RELATIONSHIP BETWEEN THE NUMBER OF TRAVELERS AND BEACH SERVICES IN SPAIN. WIT Transactions on Ecology and the Environment, 227, 43-51.

Gómez-Martín, M. B. (2006). Climate potential and tourist demand in Catalonia (Spain) during the summer season. Climate Research, 32(1), 75-87.

Hadad, S., Hadad, Y., Malul, M., \& Rosenboim, M. (2012). The economic efficiency of the tourism industry: a global comparison. Tourism economics, 18(5), 931-940.

Harper Jr, D. W. (2001). Comparing tourists crime victimization. Annals of Tourism Research, 28(4), 1053-1056.

Hayami, Y. (1969). Sources of agricultural productivity gap among selected countries. American Journal of Agricultural Economics, 51(3), 564-575. 
Hein, L., Metzger, M. J., \& Moreno, A. (2009). Potential impacts of climate change on tourism; a case study for Spain. Current Opinion in Environmental Sustainability, 1(2), 170-178.

Herrero-Prieto, L. C., \& Gomez-Vega, M. (2017). Cultural resources as a factor in cultural tourism attraction: Technical efficiency estimation of regional destinations in Spain. Tourism Economics, 23(2), 260-280.

Huang, C. W., Ting, C. T., Lin, C. H., \& Lin, C. T. (2013). Measuring non-convex metafrontier efficiency in international tourist hotels. Journal of the Operational Research Society, 64(2), 250-259.

Lam, S. W., Low, J. M., \& Tang, L. C. (2009). Operational efficiencies across Asia Pacific airports. Transportation Research Part E: Logistics and Transportation Review, 45(4), 654-665.

Leibenstein, H. (1966). Allocative efficiency vs." X-efficiency". The American Economic Review, 56(3), 392-415.

Leiper, N. (1990). Tourist attraction systems. Annals of tourism research, 17(3), 367-384.

Levantis, T., \& Gani, A. (2000). Tourism demand and the nuisance of crime. International Journal of Social Economics, 27(7/8/9/10), 959-967.

Lew, A. A. (1987). A framework of tourist attraction research. Annals of tourism research, 14(4), 553-575.

Liebert, V., \& Niemeier, H. M. (2013). A survey of empirical research on the productivity and efficiency measurement of airports. Journal of Transport Economics and Policy (JTEP), 47(2), 157-189. 
Lin, C. H., Chiu, Y. H., \& Huang, C. W. (2012). Assessment of technology gaps of tourist hotels in productive and service processes. The Service Industries Journal, 32(14), 23292342.

Lozano, S., \& Gutiérrez, E. (2011). Efficiency analysis of EU-25 member states as tourist destinations. International Journal of Services Technology and Management, 15(1-2), 6988.

Lu, Y. H., \& Chen, C. F. (2012). Research note: Analysing the efficiency of the Taiwanese hotel industry: a stochastic metafrontier approach. Tourism Economics, 18(5), 11431150 .

Martin, J. C., Mendoza, C., \& Roman, C. (2017). Regional Spanish Tourism Competitiveness. A DEA-MONITUR approach. Region, 4(3), 153-173.

Mayer, M., Müller, M., Woltering, M., Arnegger, J., \& Job, H. (2010). The economic impact of tourism in six German national parks. Landscape and Urban Planning, 97(2), 73-82.

Medal-Bartual, A., Garcia-Martin, C. J., \& Sala-Garrido, R. (2012). Efficiency analysis of small franchise enterprises through a DEA metafrontier model. The Service Industries Journal, 32(15), 2421-2434.

Mei, G., Gan, J., \& Zhang, N. (2015). Metafrontier environmental efficiency for China's regions: A slack-based efficiency measure. Sustainability, 7(4), 4004-4021.

Molinos-Senante, M., Maziotis, A., \& Sala-Garrido, R. (2015). Assessing the relative efficiency of water companies in the English and welsh water industry: a metafrontier approach. Environmental Science and Pollution Research, 22(21), 16987-16996.

Munoz, T. G. (2007). German demand for tourism in Spain. Tourism Management, 28(1), $12-22$. 
New, M., Lister, D., Hulme, M., \& Makin, I. (2002). A high-resolution data set of surface climate over global land areas. Climate research, 21(1), 1-25.

O'Donnell, C. J., Rao, D. P., \& Battese, G. E. (2008). Meta-frontier frameworks for the study of firm-level efficiencies and technology ratios. Empirical economics, 34(2), 231255.

Pendleton, L., King, P., Mohn, C., Webster, D. G., Vaughn, R., \& Adams, P. N. (2011). Estimating the potential economic impacts of climate change on Southern California beaches. Climatic Change, 109(1), 277-298.

Peypoch, N. (2007). On measuring tourism productivity. Asia Pacific Journal of Tourism Research, 12(3), 237-244.

Pizam, A. (1999). A comprehensive approach to classifying acts of crime and violence at tourism destinations. Journal of travel research, 38(1), 5-12.

Ruttan, V. W., \& Hayami, Y. (1970). Agricultural Productivity Differences Across Countries. American Economic Review, 60, 895-911.

Sala-Garrido, R., Molinos-Senante, M., \& Hernández-Sancho, F. (2011). Comparing the efficiency of wastewater treatment technologies through a DEA metafrontier model. Chemical Engineering Journal, 173(3), 766-772.

Samoilenko, S., \& Osei-Bryson, K. M. (2008). Increasing the discriminatory power of DEA in the presence of the sample heterogeneity with cluster analysis and decision trees. Expert Systems with Applications, 34(2), 1568-1581.

Santana-Gallego, M., RossellÃ-Nadal, J., \& Fourie, J. (2016). The effects of terrorism, crime and corruption on tourism. Economic Research Southern Africa (ERSA), 595, 1-28. 
Sellers-Rubio, R., \& Casado-Díaz, A. B. (2018). Analyzing hotel efficiency from a regional perspective: The role of environmental determinants. International Journal of Hospitality Management, 75, 75-85.

Simar, L., \& Wilson, P. W. (2007). Estimation and inference in two-stage, semi-parametric models of production processes. Journal of econometrics, 136(1), 31-64.

Soysal-Kurt, H. (2017). Measuring tourism efficiency of European countries by using data envelopment analysis. European Scientific Journal, 13(10), 31-49.

The Tourist $\quad$ Movement $\quad$ Borders. https://www.ine.es/dyngs/INEbase/es/operacion.htm?c=Estadistica_C\&cid=1254736176 996\&menu=ultiDatos\&idp=1254735576863

Tiedemann, T., Francksen, T., \& Latacz-Lohmann, U. (2011). Assessing the performance of German Bundesliga football players: a non-parametric metafrontier approach. Central European Journal of Operations Research, 19(4), 571-587.

United World Tourism Organization. http://www2.unwto.org

Wang, Q., Zhou, P., Ge, S., \& Zhao, Z. (2014). An International Comparison of Carbon Dioxide Emission Performance Using the Nonparametric Metafrontier Approach. Polish Journal of Environmental Studies, 23(3).

Word Bank. http://data.worldbank.org

World Travel and Tourism Council. https://www.wttc.org

Yu, M. M., \& Chen, L. H. (2019). Evaluation of efficiency and technological bias of tourist hotels by a meta-frontier DEA model. Journal of the Operational Research Society, 1-15. 
Yu, Y., Choi, Y., \& Zhang, N. (2015). Strategic corporate sustainability performance of Chinese state-owned listed firms: A meta-frontier generalized directional distance function approach. The Social Science Journal, 52(3), 300-310.

Zha, J., Zhu, Y., He, D., Tan, T., \& Yang, X. (2019). Sources of tourism growth in Mainland China: An extended data envelopment analysis-based decomposition analysis. International Journal of Tourism Research.

Zhang, N., Zhou, P., \& Choi, Y. (2013). Energy efficiency, CO2 emission performance and technology gaps in fossil fuel electricity generation in Korea: A meta-frontier nonradial directional distance functionanalysis. Energy Policy, 56, 653-662. 
Table 1: DEA oriented Meta-frontier approach timetable

\begin{tabular}{|l|l|l|l|}
\hline$\#$ & Article & Applied method & Year \\
\hline 1 & $\begin{array}{l}\text { Assaf and } \\
\text { Matawie }\end{array}$ & Bootstrapping method & 2010 \\
\hline 2 & $\begin{array}{l}\text { Sala-Garrido et } \\
\text { al. }\end{array}$ & Non-concave Meta-frontier DEA & 2011 \\
\hline 3 & Tiedemann et al. & Non-concave Meta-frontier DEA & 2011 \\
\hline 4 & $\begin{array}{l}\text { Sala Garrido et } \\
\text { al. }\end{array}$ & Ratio form to compute the technology gap & 2011 \\
\hline 5 & Chiu et al. & $\begin{array}{l}\text { Hybrid Meta-frontier DEA to distinguish inputs and } \\
\text { outputs into radial inputs and outputs }\end{array}$ & 2013 \\
\hline 6 & Chiu et al. & $\begin{array}{l}\text { Meta-frontier DEA model based on the two-stage } \\
\text { network directional distance function with quasi-fixed } \\
\text { inputs }\end{array}$ & 2013 \\
\hline 7 & Zhang et al. & Meta-frontier non-radial directional distance function & 2013 \\
\hline 8 & Yu et al. & $\begin{array}{l}\text { Meta-frontier generalised directional distance function } \\
\text { approach from O'Donnell et al. (2008) and Fare and } \\
\text { Grosskopf (2010) }\end{array}$ & 2015 \\
\hline 9 & Mei et al. & Meta-frontier slack-based efficiency measure & 2015 \\
\hline 10 & Chiu et al. & $\begin{array}{l}\text { Meta-frontier DEA model with the two-stage network } \\
\text { directional distance function }\end{array}$ & 2016 \\
\hline
\end{tabular}


Figure 1: Framework of this study.

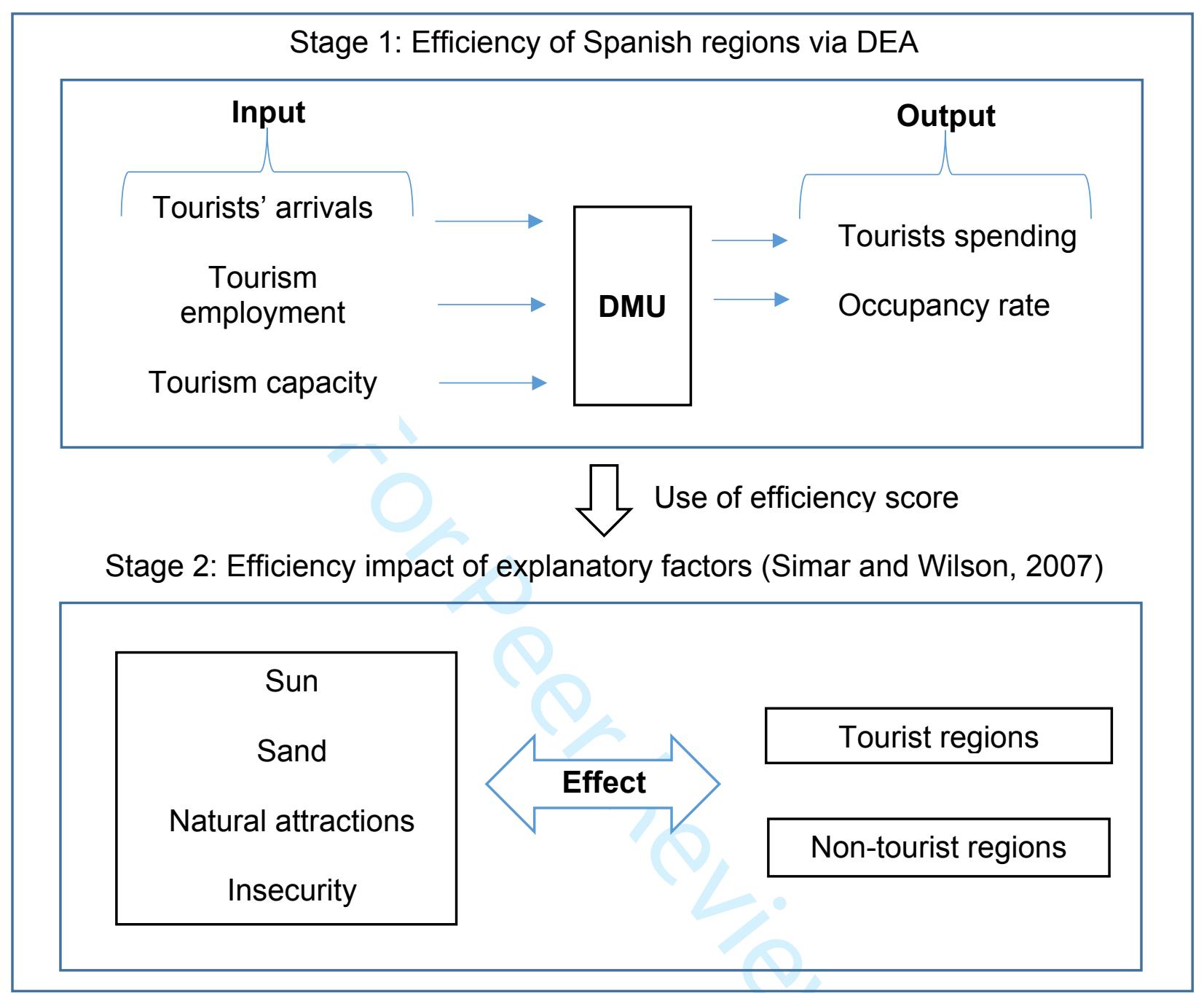

SOURCE: Self-elaboration. 
Table 2: Variables for the Simar and Wilson (2007) analysis of determinants.

\begin{tabular}{ll}
\hline Factor & Description \\
\hline SUN & The destinations climate is one of the main factors considered by \\
travellers (Hein et al., 2009). Gómez-Martín (2006) shows that the \\
sun is considered as an uncontrollable tourism attractor in Spanish \\
destinations. The total number of hours of sunshine per year (2008- \\
2018) has been used as a proxy of the variable. The data for our \\
analysis has been gathered by the State Meteorological Agency \\
(AEMET, http://www.aemet.es/es/portada).
\end{tabular}

SAND Beaches are a crucial driver of RT in Spain (Gisbert et al., 2018). Hence the primary motivation for $60 \%$ of the tourists coming to Spain is to enjoy the sun and beaches (New et al., 2002). Studies moreover show that the economic effects of beaches are significant to local communities (Pendleton et al., 2011). The length of beaches $(\mathrm{km})$ by region was used as a determining factor in the analysis. The data has been obtained in the National Statistical Institute (INE, https://www.ine.es).

NATURAL National parks are considered as an uncontrollable attractor that ATTRACTIONS create considerable income for adjacent communities and can diversify regional tourism (Mayer et al., 2010). Besides, national parks have an economic impact on the regions (Buultjens and Luckie, 2004). 15 Spanish national parks were used in the analysis. Variable dummy takes the value 0 if the region has no national parks and 1 if otherwise. Data for these have been obtained in the Spanish Ministry for the Ecological Transition (MITECO, http://www.miteco.gob.es).

INSECURITY Security affects tourism demand (Harper 2001; George 2003). Studies on return visits also show that tourists are more likely to be deterred from travelling or returning to dangerous countries or regions in which there are security concerns (Alegre and Cladera, 
2006). For example, when the tragic events of September 11th occurred, the image of international tourism was severely damaged, and travellers cancelled their planned trips due to perceived increased risk (Akama and Kieti 2003). The insecurity factor is measured by the number of crimes recorded by the Spanish police department by regions (2008-2018). The data obtained from the National Statistical Institute (INE, https://www.ine.es).

SOURCE: Self-elaboration. 
Table 3: Summary statistics of inputs and outputs

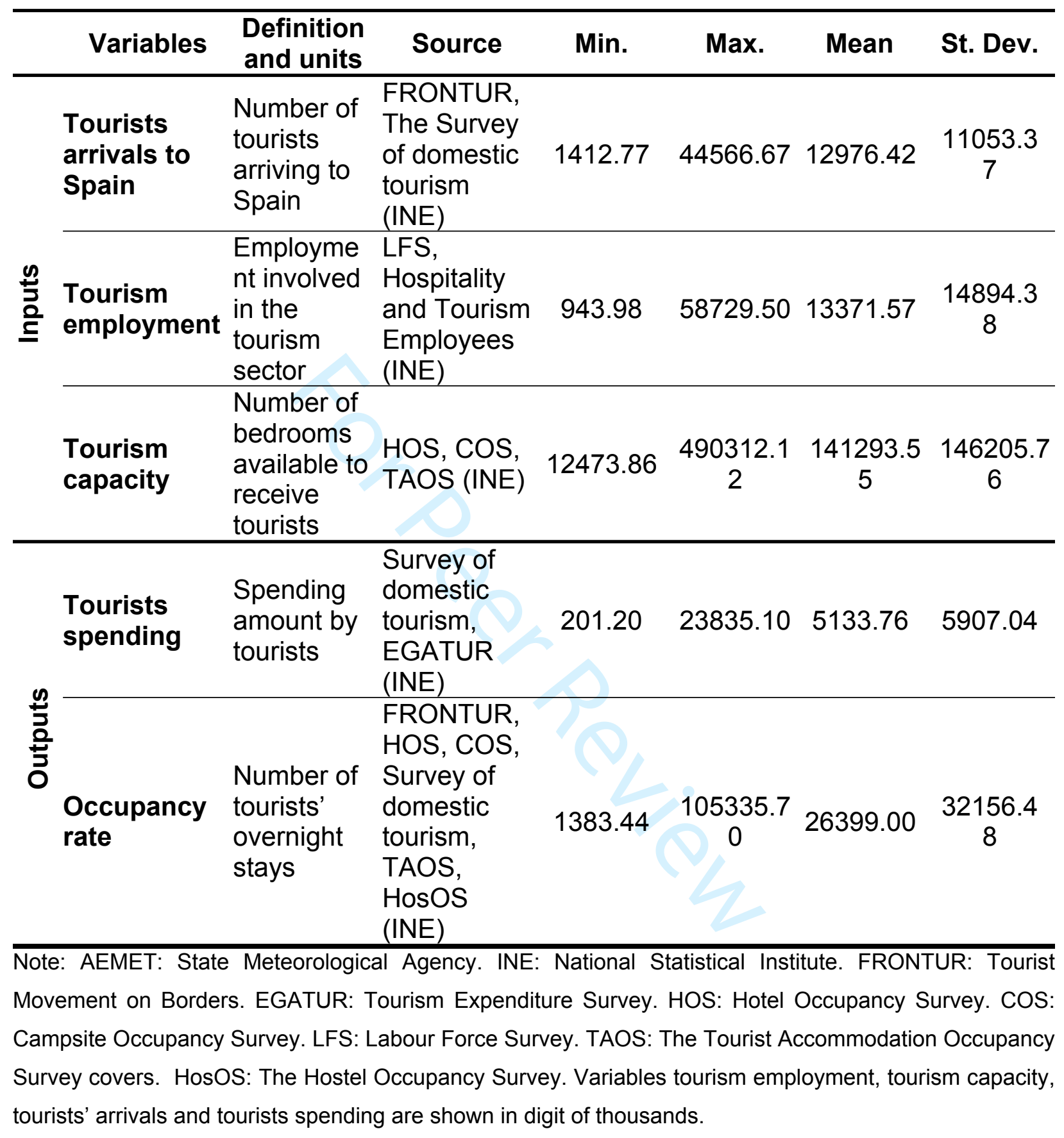


Table 4: Summary statistics of variables in averages by regions for 2008-2018

\begin{tabular}{|c|c|c|c|c|c|}
\hline $\begin{array}{l}\text { Non-tourist } \\
\text { regions }\end{array}$ & $\begin{array}{l}\text { Tourism } \\
\text { capacity }\end{array}$ & $\begin{array}{c}\text { Tourism } \\
\text { employment }\end{array}$ & $\begin{array}{l}\text { Tourists } \\
\text { arrivals to } \\
\text { Spain }\end{array}$ & $\begin{array}{l}\text { Occupancy } \\
\text { rate }\end{array}$ & $\begin{array}{l}\text { Tourists } \\
\text { spending }\end{array}$ \\
\hline Pais Vasco & 39212.66 & 4379.20 & 5226.27 & 6641.20 & 1734.73 \\
\hline Cantabria & 39098.11 & 2560.45 & 3991.07 & 4407.17 & 821.32 \\
\hline Asturias & 40936.12 & 3153.76 & 4759.03 & 4567.84 & 999.69 \\
\hline Aragon & 68330.05 & 4733.31 & 7619.92 & 7243.94 & 1191.14 \\
\hline Galicia & 82459.19 & 7320.15 & 9616.08 & 10404.69 & 1906.79 \\
\hline Rioja & 14238.86 & 1008.39 & 1710.59 & 1466.18 & 247.89 \\
\hline Castilla - Leon & 47878.81 & 3897.47 & 12025.24 & 4348.08 & 1273.46 \\
\hline $\begin{array}{l}\text { Navarra } \\
\text { Castilla - La }\end{array}$ & 24407.12 & 1925.67 & 2914.16 & 2547.95 & 489.87 \\
\hline Mancha & 87457.08 & 7844.95 & 17479.97 & 9356.92 & 2498.78 \\
\hline Extremadura & 28150.52 & 2694.52 & 4967.85 & 2846.58 & 742.34 \\
\hline Tourist regions & & & & & \\
\hline Balears Illes & 236510.46 & 30446.66 & 14178.27 & 73719.68 & 11692.19 \\
\hline $\begin{array}{l}\text { Canarias } \\
\text { Comunitat }\end{array}$ & 395995.67 & 50444.42 & 16292.57 & 101545.83 & 13473.15 \\
\hline Valenciana & 280334.90 & 18141.28 & 23560.24 & 45169.85 & 8903.85 \\
\hline Cataluna & 467683.63 & 34089.75 & 38244.43 & 79574.13 & 17599.41 \\
\hline Madrid & 129798.27 & 15246.02 & 16269.45 & 25413.53 & 8140.63 \\
\hline Murcia & 40939.13 & 2724.84 & 4344.06 & 5167.97 & 1158.15 \\
\hline Andalucia & 378559.77 & 36705.80 & 37399.89 & 64361.52 & 14400.54 \\
\hline
\end{tabular}


Table 5: The average scores of efficiency of tourist and non-tourist regions in Spain (20082018) ranked overall technical efficiency (CRS), pure technical efficiency (VRS) and scale efficiency.

\begin{tabular}{llll}
\hline Region & $\begin{array}{c}\text { Overall } \\
\text { technical } \\
\text { efficiency } \\
\text { (CRS) }\end{array}$ & $\begin{array}{c}\text { Pure technical } \\
\text { efficiency (VRS) }\end{array}$ & $\begin{array}{c}\text { Scale } \\
\text { efficiency }\end{array}$ \\
\hline Non-tourist regions & & & \\
\hline Pais Vasco & 0.69 & 0.83 & 0.82 \\
\hline Cantabria & 0.66 & 0.80 & 0.82 \\
\hline Asturias & 0.58 & 0.69 & 0.84 \\
\hline Aragon & 0.58 & 0.65 & 0.88 \\
\hline Galicia & 0.56 & 0.60 & 0.93 \\
\hline Rioja & 0.55 & 1.00 & 0.55 \\
\hline Castilla - Leon & 0.52 & 0.56 & 0.94 \\
\hline Navarra & 0.51 & 0.74 & 0.69 \\
\hline Castilla - La Mancha & 0.51 & 0.60 & 0.84 \\
\hline Extremadura & 0.46 & 0.68 & 0.69 \\
\hline Average & $\mathbf{0 . 5 6}$ & $\mathbf{0 . 7 2}$ & $\mathbf{0 . 8 0}$ \\
\hline & & & \\
\hline Tourist regions & & & 1.00 \\
\hline Balears IIles & 1.00 & 1.00 & 0.99 \\
\hline Canarias & 0.99 & 1.00 & 1.00 \\
\hline Comunitat Valenciana & 0.96 & 0.96 & 0.98 \\
\hline Cataluna & 0.94 & 0.97 & 0.98 \\
\hline Madrid & 0.85 & 0.87 & 0.87 \\
\hline Murcia & 0.77 & 0.88 & 0.97 \\
\hline Andalucia & 0.73 & 0.75 & $\mathbf{0 . 9 7}$ \\
\hline Average & $\mathbf{0 . 8 9}$ & $\mathbf{0 . 9 2}$ & $\mathbf{0 . 8 7}$ \\
\hline Average in total & $\mathbf{0 . 7 0}$ & $\mathbf{0 . 8 0}$ & \\
\hline SouRCE: Self-elaboration & & & \\
\hline
\end{tabular}


Table 6: Parameter estimates for the Simar-Wilson regression model of tourist and nontourist regions in Spain (2008-2018).

\begin{tabular}{|c|c|c|c|c|}
\hline \multirow[b]{2}{*}{ Explanatory factors } & \multicolumn{2}{|c|}{$\begin{array}{l}\text { Overall technical } \\
\text { efficiency -CRS- (z- } \\
\text { statistic) }\end{array}$} & \multicolumn{2}{|c|}{$\begin{array}{l}\text { Pure technical efficiency } \\
\text {-VRS- (z-statistic) }\end{array}$} \\
\hline & $\begin{array}{l}\text { Tourist } \\
\text { regions }\end{array}$ & $\begin{array}{l}\text { Non-tourist } \\
\text { regions }\end{array}$ & $\begin{array}{l}\text { Tourist } \\
\text { regions }\end{array}$ & $\begin{array}{l}\text { Non-tourist } \\
\text { regions }\end{array}$ \\
\hline SUN & $\begin{array}{l}-0.0105^{\star \star} \\
(-2.41)\end{array}$ & $\begin{array}{c}-0.0018^{* * *} \\
(-6.22)\end{array}$ & $\begin{array}{c}-0.0074^{* \star \star} \\
(-3.64)\end{array}$ & $\begin{array}{c}-0.0013^{* *} \\
(-2.18)\end{array}$ \\
\hline SAND & $\begin{array}{c}0.0002^{*} \\
(1.83)\end{array}$ & $\begin{array}{c}0.0000 \\
(0.98)\end{array}$ & $\begin{array}{c}-0.0002 \\
(-0.49)\end{array}$ & $\begin{array}{c}0.0002^{*} \\
(1.79)\end{array}$ \\
\hline $\begin{array}{c}\text { NATURAL } \\
\text { ATTRACTIONS }\end{array}$ & $\begin{array}{l}0.0998 \\
(0.87)\end{array}$ & $\begin{array}{c}0.0414^{* *} \\
(2.08)\end{array}$ & $\begin{array}{l}-0.0162 \\
(-0.17)\end{array}$ & $\begin{array}{l}0.0095 \\
(0.26)\end{array}$ \\
\hline INSECURITY & $\begin{array}{l}-8.4200^{*} \\
(-1.84)\end{array}$ & $\begin{array}{c}-1.3200 \\
(-0.41)\end{array}$ & $\begin{array}{c}-1.5500^{* \star \star} \\
(-3.42)\end{array}$ & $\begin{array}{l}-4.4100 \\
(-0.69)\end{array}$ \\
\hline
\end{tabular}

Notes: ${ }^{* * *},{ }^{* *}$, and ${ }^{*}$ : Below the $1 \%, 5 \%$ and $10 \%$ statistical significance thresholds, respectively. Likelihood ratio chi-square $(\mathrm{df}=2)$ 
Table 7: Technical efficiency $\left(\boldsymbol{T} \boldsymbol{E}^{\boldsymbol{k}}\right)$, Metafrontier efficiency $\left(\boldsymbol{T} \boldsymbol{E}^{\text {meta}}\right)$ and technological gaps (TGR)

\begin{tabular}{|c|c|c|}
\hline Criteria & Average & Std. Dev. \\
\hline All regions & Average & Std. Dev. \\
\hline Technical efficiency & 0.84 & 0.12 \\
\hline Metafrontier efficiency & 0.70 & 0.19 \\
\hline Technology Gap Ratio & 0.82 & 0.15 \\
\hline Tourist regions & Average & Std. Dev. \\
\hline Technical efficiency & 0.89 & 0.12 \\
\hline Metafrontier efficiency & 0.89 & 0.12 \\
\hline Technology Gap Ratio & 1.00 & 0.00 \\
\hline 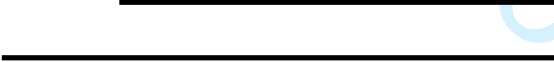 & & \\
\hline Non-tourist regions & Average & Std. Dev. \\
\hline Technical efficiency & 0.70 & 0.12 \\
\hline Metafrontier efficiency & 0.56 & 0.08 \\
\hline Technology Gap Ratio & 0.70 & 0.06 \\
\hline
\end{tabular}


Figure 2: Evolution of Technology Gap Ratio (TGR) by groups (2008-2018).

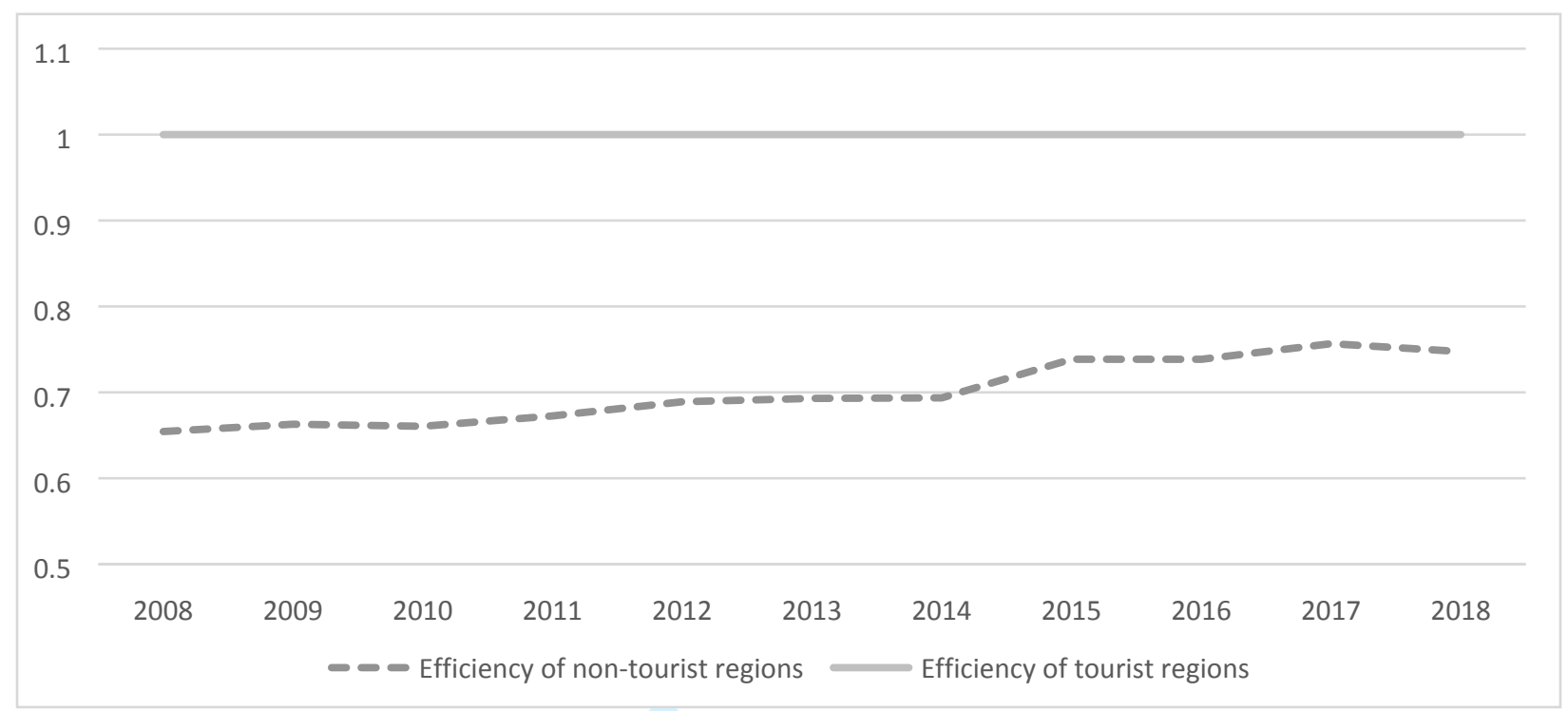

SOURCE: Self-elaboration.

https://mc.manuscriptcentral.com/teu 
The authors take this opportunity to thank the reviewers of our paper for their kind collaboration to the improvement of this paper. We have analyzed the comments carefully, and several corrections have been made, which we hope will meet with your approval. In the revision report and manuscript, the answers or explanations are written in blue, and the newly added contents are in red.

Reviewer(s)' Comments to Author: Referee: 1 Comments to the Author

The paper evaluates the efficiency of tourism in Spanish regions by using a meta-frontier DEA approach. This helps to deal with the heterogeneity of regions, divided in two groups according to their tourist or non-tourist vocation. In particular, the aim is to assess the determinants of efficiency (with a second stage analysis based on the Simar-Wilson 2007 methodology). One of the main results indicate that the (in)security is an important factor that explain the performance of tourist regions (while it does not affect non-tourist regions). I think the idea behind the paper is very interesting and the methodological approach is sound. Security is certainly an important driver of tourism demand and this study proves it with an innovative approach. For this reason, I have only some technical issues that I would like the authors to deal with.

The authors feel very grateful for the reviewer's comments since we consider them a recognition of the work done.

1. I have some doubts on the set of input-output used in the analysis. In particular, I cannot understand the rational for having "tourists arrivals" as an input (I would see it rather as an output). Does it makes sense a model where you "minimize" (as an input) the number of tourist arrivals?

The authors would like to thank the referee for noting this issue as we consider it crucial for a good efficiency analysis. At first glance, Tourists arrivals and the number of overnight stays could be considered two similar concepts. However, it can also be considered as a process in which tourists arrivals transforms into bed-nights and tourist spending. This distinction allows us to discuss tourism performance through the length of stay and the spending. Thus, it is possible to have a large number of arrivals for a few bed-nights, a situation that is symptomatic for an inefficient destination. In this work, "tourism arrivals" has been considered as an input variable since we consider that it makes a better approximation of the economic returns of tourism.

The following paragraph has been added to explain the problem when categorizing tourism arrivals ( $p .11)$ :

Tourism is a type of multi-product process. Numerous variables are of interest for the analysis of the tourist efficiency and productivity of a region. These variables are usually related to accommodation capacity and employment as inputs and, the length of stay (bed-nights) and tourist spending as outputs (Fuchs, 2004; Cracolici et al., 2007; Botti et al., 2009; Barros et al., 2011; Assaf and Josiassen, 2012; Assaf and Tsionas, 2015; Cuccia et al., 2016). However, the identification of inputs and outputs in the measure of tourism efficiency is still an open question since there is no consensus on whether "arrivals" should be considered an input or an output. On the one hand, "tourist arrivals" can be understood as the result (output) of the utilization of tourist inputs (Assaf and Josiassen, 2012; Assaf and Tsionas, 2015; Cracolici et al., 2007; Fuchs, 2004). On the other hand, tourism can also be considered as a process in which "arrivals" (input) is transformed into overnight stays (bed-nights) and tourist spending (Peypoch and Solonandrasana, 2007; Botti et al., 2009; Barros et al., 2011; Cuccia et al., 2016).

2. Please provide a better explanation of what the variable concerning "occupancy" measures - and how it relates to tourists arrivals. Also, please rename the variable as "occupancy" instead of "occupancy rate", since "occupancy rate" would refer to a percentage.

As can be deduced from the reviewer's comment, the name of the "occupancy rate" variable resulted in a misinterpretation of its true meaning. Therefore, in the current version of the manuscript, the variable name has been modified to "Tourist stay" since we believe it is more accurate. The variable aims to measure the total length of stay of tourists in each region. Thus, the total number of overnight spent in tourist accommodation establishments has been used as a proxy of the tourist stay. To provide greater clarity to the explanation of the data, all variables have been explained in a more precise way (p.11,12).

In the first stage of the analysis, output and input variables have been chosen based on a review of the literature mentioned in section 2, and the data at our disposal. As input variables, this study includes Tourists arrivals measured by the number of tourists (both domestic and foreign) arriving to the region, Tourism employment measured by the number of employees involved in tourism, and Tourism capacity measured by the number of available bedrooms to receive tourists. As output variables, Tourists spending is measured by 
the amount of tourists' spending in MLN euros and, Tourist stay is measured by the total number of tourists' overnight stays (length of stay) in hosting places. In this work "tourism arrivals" has been considered as an input variable since we consider that it makes a better approximation of the economic returns of tourism.

Table 3, Table 4 and Figure 1 have also been modified (p. 31, 34 and 35).

Figure 1: Framework of this study.

Stage 1: Efficiency of Spanish regions via DEA

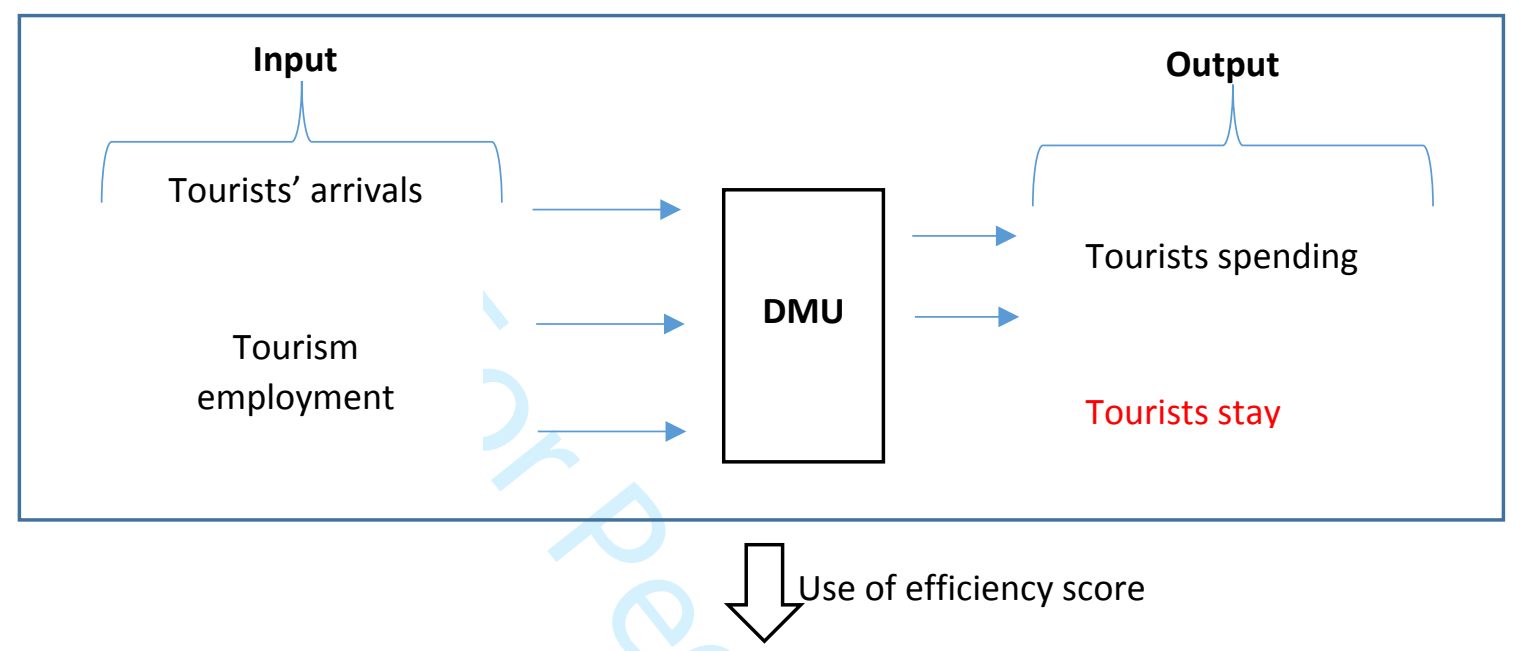

Stage 2: Efficiency impact of explanatory factors (Simar and Wilson, 2007)

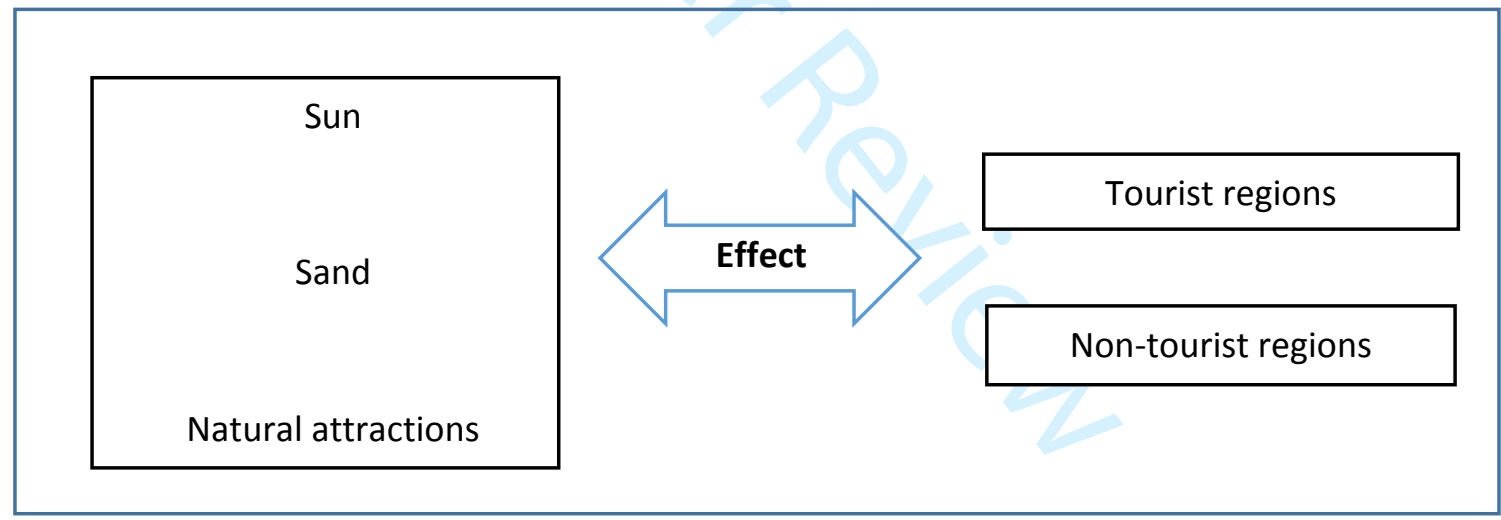

SOURCE: Self-elaboration.

Table 3: Summary statistics of inputs and outputs

\begin{tabular}{lllllll}
\hline Variables & $\begin{array}{l}\text { Definition } \\
\text { and units }\end{array}$ & Source & Min. & Max. & Mean & St. Dev. \\
\hline Tourists & $\begin{array}{l}\text { Number of } \\
\text { tourists } \\
\text { arriving to the } \\
\text { region }\end{array}$ & $\begin{array}{l}\text { FRONTUR, The } \\
\text { Survey of } \\
\text { tomestic } \\
\text { tourism (INE) }\end{array}$ & 1412.77 & 44566.67 & 12976.42 & 11053.37 \\
& & & & & \\
\hline
\end{tabular}


3. More in general, you are adopting an input-oriented approach. To me, it would seem more logical the aim of maximizing the outputs (given the inputs), thus the adoption of an output-oriented model.

The choice of the model orientation should be done based on the level of control that the agents involved in the tourism industry have on input and output variables. These choices must consider the characteristics of the data and the purpose of the analysis. We believe that Tourists spending and the length of stay is not under the control of the regional tourism industry. Thus, In the face of changes in tourism demand, the agents involved in tourism production will act by modifying the input factors (employment and infrastructure). Therefore, we consider that Spanish industry operates in a sector characterized by endogenous inputs and exogenous outputs. However, as Coelli and Perelman (1999) demonstrated, the orientation of the model should not affect the results obtained.

The following footnote has been added as an explanation to the orientation of the model (p.6)

In this research, an input-orientated model has been chosen since we believe the tourism industry faces great difficulty in modifying and moving outputs (such as tourists spending and the length of stay). Consequently, the agents involved in the tourism industry should focus on minimizing inputs. However, as Coelli and Perelman (1999) demonstrated, the orientation of the model should not affect the results obtained.

4. Finally, the authors could expand a bit their comments on results and implications in terms of policy. I think, for future research, it would be also interesting to adopt this approach to compare different countries rather than regions.

The authors would like to thank the referee for this comment since we consider it really pertinent. As suggested by the reviewer, the actual version of the manuscript contains comments on results and implications in terms of policy ( $p 17)$ : 
Referee: 2

This paper should be expanded before being published. Some considerations could be taken into account.

-The paper should be expanded for example by adding propositions, since it is theoretical -a set of propositions that derive in future empirical work would be desirable

Following the reviewer's recommendations, the following paragraph has been added including propositions for future empirical work (p17)

Our findings are also useful for both scientists and practitioners who seek to understand the relationship between tourism and efficiency. This paper contributes to the understanding of the efficiency in tourism in two aspects: First, by demonstrating the importance of heterogeneity in the study of tourism efficiency in territories. Second, by delving into the factors that determine tourism efficiency. However, there are limitations to this research. This paper focuses only on the Spanish case and results may not be generalizable. Although we found a direct relationship between the level of security and tourism efficiency, future research could be applied to other international tourist destinations. Additionally, future research could be applied to the comparison of countries rather than regions.

-A section that explains the main theories on which it is based and study would be advisable. A table that includes similar studies carried out to date could improve the theoretical framework

According to reviewer's suggestions, table 1 includes similar studies carried out to date (p30)

Table 1: DEA oriented Meta-frontier approach timetable

\begin{tabular}{|l|l|l|l|}
\hline$\#$ & Article & Applied method & Year \\
\hline 1 & Assaf and Matawie & Bootstrapping method & 2010 \\
\hline 2 & Sala-Garrido et al. & Non-concave Meta-frontier DEA & 2011 \\
\hline 3 & Tiedemann et al. & Non-concave Meta-frontier DEA & 2011 \\
\hline 4 & Sala Garrido et al. & Ratio form to compute the technology gap & 2011 \\
\hline
\end{tabular}

https://mc.manuscriptcentral.com/teu

A purpose of these studies is to inform policymakers and tourism managers on the design and implementation

\begin{abstract}
Our findings are also useful for both scientists and practitioners who seek to understand the relationship aspects: First, by demonstrating the importance of heterogeneity in the study of tourism efficiency in territories. Second, by delving into the factors that determine tourism efficiency. However, there are Although we found a direct relationship between the level of security and tourism efficiency, future research could be applied to other international tourist destinations. Additionally, future research could be applied to the comparison of countries rather than regions. The above results are meaningful to policymakers. From the results obtained, it can be concluded that a to adapt their tourism model to a new context where security and nature are crucial factors. From this point of view, the results of the study can, above all, be considered as an essential guide for regional authorities to maximize the use of geographical and natural advantages to attract tourists as a source of economic development. limitations to this research. This paper focuses only on the Spanish case and results may not be generalizable.
\end{abstract} of appropriate instruments for enhancing the performance of the tourism industry. Our empirical results
describe the efficiency of the sector in Spain and are relevant to establish what factors are significant in the performance of Spanish RT. This research is relevant regarding the importance of security in tourism. For years the competition of international tourist destinations specialized in the sun and sand model has increased. In this new scenario, security seems to be a determining factor in the success of a tourist destination.
Furthermore, natural attractions seem to be a driving force for increasing the tourism efficiency of regions that were not traditionally specialized in tourism. . 


\begin{tabular}{|l|l|l|l|}
\hline 5 & Chiu et al. & $\begin{array}{l}\text { Hybrid Meta-frontier DEA to distinguish inputs and outputs into } \\
\text { radial inputs and outputs }\end{array}$ & 2013 \\
\hline 6 & Chiu et al. & $\begin{array}{l}\text { Meta-frontier DEA model based on the two-stage network } \\
\text { directional distance function with quasi-fixed inputs }\end{array}$ & 2013 \\
\hline 7 & Zhang et al. & Meta-frontier non-radial directional distance function & 2013 \\
\hline 8 & Yu et al. & $\begin{array}{l}\text { Meta-frontier generalised directional distance function approach } \\
\text { from O'Donnell et al. (2008) and Fare and Grosskopf (2010) }\end{array}$ & 2015 \\
\hline 9 & Mei et al. & Meta-frontier slack-based efficiency measure & 2015 \\
\hline 10 & Chiu et al. & $\begin{array}{l}\text { Meta-frontier DEA model with the two-stage network directional } \\
\text { distance function }\end{array}$ & 2016 \\
\hline
\end{tabular}

-The results should be shown in a figure, as well as the relationships studied and compliance or not of the hypotheses. For the reader it would be much easier to understand.

Following the reviewer's recommendations, a figure with the results by Regions is included in the current version of the manuscript (38).

Figure 2: Tourism efficiency in Spain

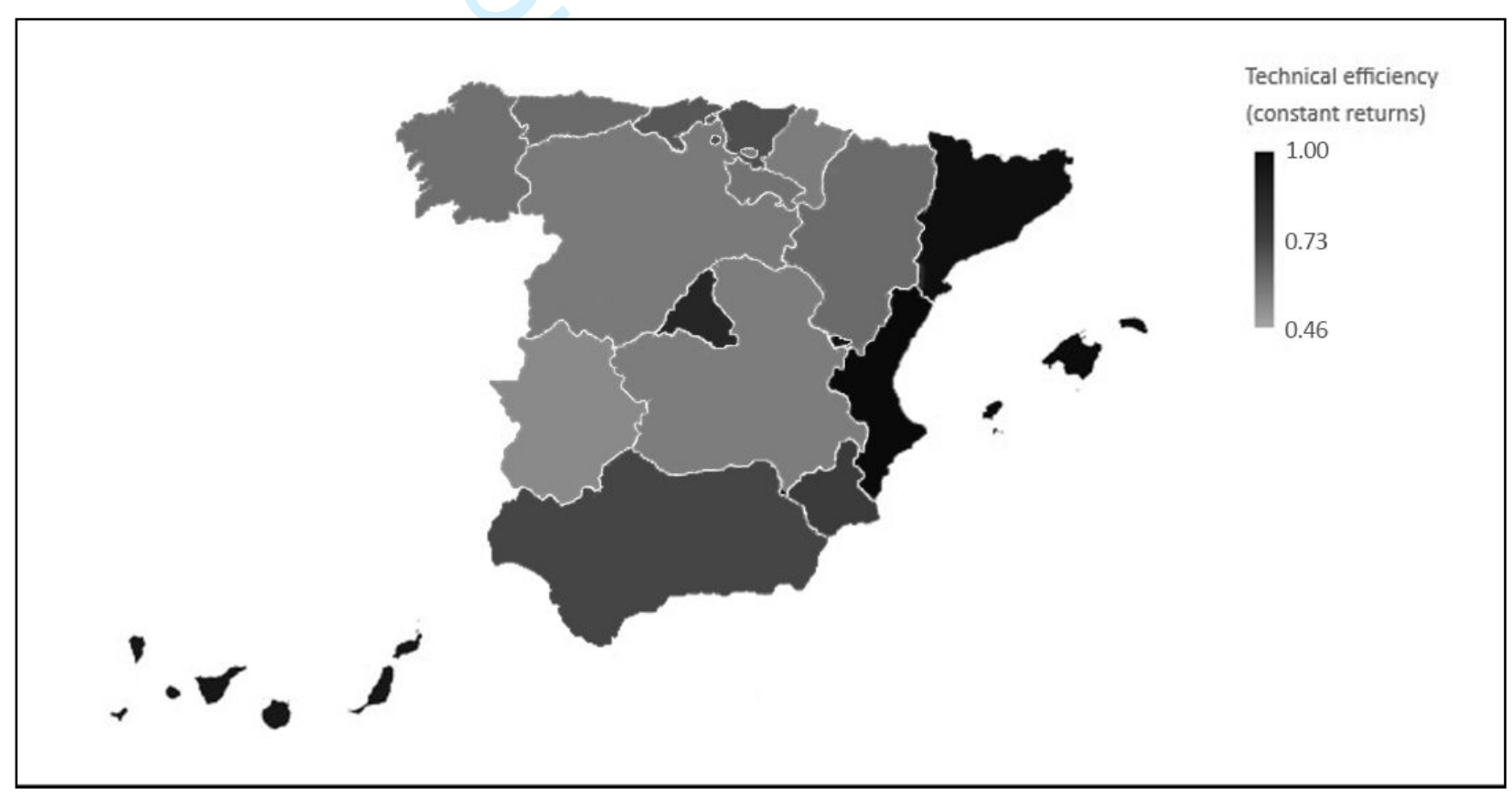

In addition, the current version of the manuscript includes the expected signs (table 2 ) for the variables determining efficiency (p.32).

Table 2: Variables for the Simar and Wilson (2007) analysis of determinants.

\begin{tabular}{lll}
\hline Factor & Description & $\begin{array}{l}\text { Expected } \\
\text { sing }\end{array}$ \\
\hline SUN & The destinations climate is one of the main factors considered by & Positive \\
& travellers (Hein et al., 2009). Gómez-Martín (2006) shows that the & \\
& sun is considered as an uncontrollable tourism attractor in Spanish \\
& destinations. The total number of hours of sunshine per year (2008-
\end{tabular}


2018) has been used as a proxy of the variable. The data for our analysis has been gathered by the State Meteorological Agency (AEMET, http://www.aemet.es/es/portada).

SAND

NATURAL

ATTRACTIONS

INSECURITY
Beaches are a crucial driver of RT in Spain (Gisbert et al., 2018). Hence the primary motivation for $60 \%$ of the tourists coming to Spain is to enjoy the sun and beaches (New et al., 2002). Studies moreover show that the economic effects of beaches are significant to local communities (Pendleton et al., 2011). The length of beaches $(\mathrm{km})$ by region was used as a determining factor in the analysis. The data has been obtained in the National Statistical Institute (INE, https://www.ine.es).

National parks are considered as an uncontrollable attractor that create considerable income for adjacent communities and can diversify regional tourism (Mayer et al., 2010). Besides, national parks have an economic impact on the regions (Buultjens and Luckie, 2004). 15 Spanish national parks were used in the analysis. Variable dummy takes the value 0 if the region has no national parks and 1 if otherwise. Data for these have been obtained in the Spanish Ministry for the Ecological Transition (MITECO, http://www.miteco.gob.es).

Security affects tourism demand (Harper 2001; George 2003). Negative Studies on return visits also show that tourists are more likely to be deterred from travelling or returning to dangerous countries or regions in which there are security concerns (Alegre and Cladera, 2006). For example, when the tragic events of September 11th occurred, the image of international tourism was severely damaged, and travellers cancelled their planned trips due to perceived increased risk (Akama and Kieti 2003). The insecurity factor is measured by the number of crimes recorded by the Spanish police department by regions (2008-2018). The data obtained from the National Statistical Institute (INE, https://www.ine.es).
Positive

Positive 
-The academic implications and for the practitioners are not included in the text. At least two of each type should be considered. The future research could be added.

The authors are grateful for this comment, as they consider it very pertinent. Following the reviewer's recommendations, the conclusions have been modified to include academic and practitioners implications (p.17)

This research is relevant regarding the importance of security in tourism. For many years, the Spanish tourism model has based its success on the sun and sand factors. However, in recent years the competition of international tourist destinations specialized in the sun and sand model has increased. In this new scenario, security seems to be a determining factor in the success of a tourist destination. Furthermore, natural attractions seem to be a driving force for increasing the tourism efficiency of regions that were not traditionally specialized in tourism.

The above results are meaningful to policymakers. From the results obtained, it can be concluded that a favorable climate is not in itself a guarantee of tourism. Regions traditionally specialized in tourism should try to adapt their tourism model to a new context where security and nature are crucial factors. From this point of view, the results of the study can, above all, be considered as an essential guide for regional authorities to maximize the use of geographical and natural advantages to attract tourists as a source of economic development.

Our findings are also useful for both scientists and practitioners who seek to understand the relationship between tourism and efficiency. This paper contributes to the understanding of the efficiency in tourism in two aspects: First, by demonstrating the importance of heterogeneity in the study of tourism efficiency in territories. Second, by delving into the factors that determine tourism efficiency. However, there are limitations to this research. This paper focuses only on the Spanish case and results may not be generalizable. Although we found a direct relationship between the level of security and tourism efficiency, future research could be applied to other international tourist destinations. Additionally, future research could be applied to the comparison of countries rather than regions. 
The change of the Spanish tourist model: from the Sun and Sand to the Security and Sand

\begin{abstract}
There is evidence of specialisation in tourism destinations, but also a lack of literature regarding its impact on tourism regional performance. This study aims to contribute to the analysis of the determinants of tourism performance. To this end, the efficiency of 17 Spanish regions has been estimated by meta-frontier DEA techniques over the 2008-2018 period. In the second stage, we adopt the bootstrapping method proposed by Simar and Wilson (2007) to measure the impact of explanatory factors on tourism efficiency.

The results suggest that regions specialised in tourism may achieve higher efficiency levels. However, there is evidence of a catching-up process in the tourism technology of the Spanish regions over the last ten years. Results also suggest that sand (kilometres of beaches) and insecurity are the key drivers of tourism efficiency. Moreover, natural attractions is the factor that most positively influences efficiency in non-specialised regions.
\end{abstract}

Keywords: Spain, Meta-frontier, DEA, Tourism efficiency, Regional tourism. 


\section{Introduction}

Tourism is a real global force for economic growth and development. By serving as a catalyst for innovation and entrepreneurship and creating more and better jobs, it helps to build better lives for millions of individuals (UNWTO, 2019). According to the World Travel and Tourism Council (WTTC, 2019), tourism contributes 3.2\% (\$2,750.7 billion) to the global GDP and supports one in every ten jobs in the world, generating $3.8 \%$ of the total employment in 2018.

Despite the downside risks (economic slowdown, Brexit uncertainty, etc.), the number of international travellers is still increasing worldwide (UNWTO, 2019). For years, the most popular part of the world is the European Union (EU), concentrating $39.15 \%$ of global tourism over the past decade (World Bank, 2019). The EU attracts foreign tourists by their agreeable warm climate throughout the year with rich historical culture and extensive sandy beaches.

In this sense, Spain is one of the major tourist powers, receiving $5.20 \%$ of all international tourists from all around the world over the last twenty years(World Bank, 2019). Spain has a suitable environment for natural, cultural and both sand and sea and ski tourism in most regions, due to its historical endowment and geographical situation (orographic conditions) with the Mediterranean, the semi-arid and oceanic climate. According to the Tourist Movement on Borders (Frontur, 2019), Spain received 81,786,364 international tourists in 2018.

Spain is often shown to be at the top of the list of countries with the most productive international tourism. Despite this, it is relevant to evaluate whether are differences among the efficiency of regional tourism (from now on RT) in Spain. RT means a geographical location (region) where natural and human-made environment, supplied by private and public agents, are organised and managed to attract tourists and be enjoyed by them (Botti et al., 2009; Barros et al., 2011).

This study aims to contribute to the analysis of the determinants of tourism performance. The evaluation of the drivers of tourism performance is especially relevant, due to the importance of the tourism sector in the Spanish regional economy. 


\begin{abstract}
To address the research aims, a two-stage procedure is applied. First, we carry out a
\end{abstract} meta-frontier DEA to obtain the efficiency scores. Then, we use the bootstrapping method proposed by Simar and Wilson (2007) to measure the impact of explanatory factors on the tourism efficiency of the Spanish regions. This research presents the following novelties: (1) efficiency evaluation is carried out separately by grouping regions in accordance with their tourism specialization (Non-tourist: Pais Vasco, Cantabria, Asturias, Aragon, Galicia, Rioja, Castilla - Leon, Navarra, Castilla - La Mancha, Extremadura; Tourist specialization: Balears Illes, Canarias, Comunitat Valenciana, Cataluna, Madrid, Murcia, Andalucia), which allows dealing with regional heterogeneity in the DEA estimation. (2) Efficiency determinants are evaluated separately for the two groups of regions, which enables us to see whether the impact of factors determining performance depends on the tourist orientation of the regions.

The article is organized as follows. In section 4.2., we review the literature on previous studies on the efficiency of RTs. Section 4.3. presents an empirical model for estimation. Section 4.4. describes the data and descriptive statistics of the variables used. Section 4.5. illustrates the results and section 4.6. highlights the conclusion of the research.

\title{
Literature review
}

Tourism stimulates economic research to investigate ways to use it as a driver of economic growth due to its industrial relevance. There is an increasing interest in assessing the efficiency of tourism sub-sectors (hotel, restaurant, service, tourist transportation, etc.) and the effectiveness of public policy for increasing the efficiency of RT. Various frontier models are used, from nonparametric to parametric and stochastic methods. Among the various frontier approaches the most used are two different methodologies: the parametric method, Stochastic Frontier Analysis (SFA) (Aigner et al., 1977) and the non-parametric method, Data Envelopment Analysis (DEA) (Charnes et al., 1978). The advantage of these frontier methods over regression, partial and simple productivity techniques lies in the calculation of efficiency based on the concept proposed by Farrell (1957). According to this concept, productivity is defined as the ratio of input to output and can be calculated using a single or by aggregating multiple inputs and outputs. 


\begin{abstract}
In the frontier methods, the criterion in comparing the efficiency of a Decision-making unit
\end{abstract} (DMUs) is assessing the distance of each DMU from the frontier. Thus, focusing on RT efficiency, the frontier is used as the basis for comparison between different DMUs. Nevertheless, many researchers ignore the fact that if the DMUs under study operate under different characteristics, it becomes inaccessible to use a single frontier in comparing the efficiency of the various firms (Matawie and Assaf, 2008). Such problems mainly occur when comparisons between DMUs from different groups are inaccessible. To solve this, referring to the concept of Meta-frontier proposed by Hayami (1969), and Hayami and Ruttan (1970), later Battese and Rao (2002), Battese et al. (2004) and O'Donnell et al. (2008) have addressed the issue of a single frontier when group differences exist between the different firms. An advantage of this model is that it allows for the investigation of DMUs' efficiency in different groups that operate under different characteristics. Therefore, the Meta-frontier model is considered as an envelope of all the possible group frontiers.

The approach proposed by O'Donnell et al. (2008) shows that the meta technical inefficiency under the Meta-frontier can not only be divided into two parts (technology gap inefficiency and group technical inefficiency) but also can be used to justify the direction for improvement of technology. Since the development of the Meta-frontier DEA model (O'Donnell et al., 2008) coming out, various Meta-frontier approaches based on DEA have been proposed (Assaf and Matawie (2010), Sala-Garrido et al. (2011), Tiedemann et al. (2011), Chiu et al. (2013). Table 1. shows the DEA oriented Meta-frontier approach timetable.

Table 1: DEA oriented Meta-frontier approach timetable

Likewise, since every additional update, a growing number of studies have applied various meta-frontier DEA models to measure the group efficiency, meta-efficiency and 
technology gap in multiple industries (Medal-Bartual et al., 2012, Wang et al., 2014 Molinos-Senante et al., 2015, Chen et al., 2017, among others).

Regarding the analysis of tourist efficiency, the literature has analysed tourism efficiency worldwide (Assaf and Josiassen, 2012; Hadad et al., 2012), in Europe (Abad and Kongmanwatana, 2015; Lozano and Gutiérrez, 2011; Soysal-Kurt 2017) and at regional level in Italy (Bosetti et al., 2004; Bosetti et al., 2007; Cuccia et al., 2016), France (Peypoch, 2007, Botti et al., 2009, Barros et al., 2011), Spain (Benito et al., 2014, Martin et al., 2017) among others.

In terms of applications in the tourism industry, most studies which use the Meta-frontier approach evaluate hotel performance, such as Assaf et al. (2010), Huang et al. (2013), Lin et al., (2012), Yu and Chen (2019), Cho and Wang (2018), Lu and Chen (2012), Yu and Chen (2019). Also, restaurants are assessed by Fang and Hsu (2012), Fang et al. (2013), Fang and Hsu (2014), Alberca and Parte (2018). In regional tourism (Benito et al., 2014; Cuccia et al., 2017; Assaf and Josiassen (2016); Assaf and Dwyer (2013); Zha et al., 2019).

Despite the increasing number of papers using various types of Meta-frontier approaches, the method is relatively novel in operation research (OR), and in the literature, as far as we found, there are still no studies on Spanish RT that use The Meta-frontier DEA approach.

\section{Theoretical and empirical Model}

The efficiency of RT has been analysed using different approaches such as regression analysis, productivity index, and ratio analysis. However, the frontier analysis is by far the most used approach. Frontier analysis can be applied using two different methodologies: parametric methods, such as the Stochastic Frontier Analysis (SFA) and non-parametric methods such as Data Envelopment Analysis (DEA). At the first stage of papers' analysis, we use DEA for implementing the non-concave Meta-frontier as DEA is suited to measure efficiencies of the deterministic industry for multiple inputs/outputs sets (Lam et al., 2009). 


\section{Data envelopment analysis}

DEA is a non-parametric methodology introduced by Charnes et al. (1978). Based on linear programming, it is used to measure the relative performance of a set of similar organisational units (DMUs) by using multiple measures of inputs and outputs. The DEA model determines the efficiency score for each DMU, obtained as a ratio of weighted outputs to weighted inputs.

Formally, since a total of $L=\sum_{k} L_{k}$ regions, the input-oriented ${ }^{1}$ technical efficiency under constant return to scale (CRS) is obtained by solving the following linear programming problem:

$$
\begin{gathered}
\min _{\theta_{i t}, \lambda_{i t}} \theta_{i t} \\
\text { s.t. } \theta_{i t} x_{i t}-\lambda_{i t} X \geq 0, \\
-y_{i t}+\lambda_{i t} Y \geq 0, \\
\lambda_{i t} \geq 0
\end{gathered}
$$

where $y_{i t}$ is the $M x 1$ vector of output quantity for the $i$ th region in the $t$ th period, $x_{i t}$ is the $M x 1$ vector of input quantities for the $i$ th region in the $t$ th period; $Y$ is the $M x L$ matrix of output quantities for all $L$ regions; $X$ is the $M x L$ matrix of input quantities for all $L$ regions; $\lambda_{i t}$ is an $L x 1$ non-negative vector of weights; and $\theta_{i t}$ depicts a scalar. Thus, $1 / \theta_{i t}$ is an estimate of the overall technical efficiency (OTE) of $i$ th region in the $t$ th period under CRS. By adding the constraint of convexity on the model (Variables Returns to Scale), one can find the technical efficiency arising from optimal management practices, called pure technical efficiency (PTE) (Banker et al., 1984). Finally, the technical efficiency due to optimal or suboptimal production scale, scale efficiency (SE) can be obtained by the ratio between OTE and PTE (Coelli et al., 2005).

\section{The Meta-frontier model}

\footnotetext{
${ }^{1}$ In this research, an input-orientated model has been chosen since we believe the tourism industry faces great difficulty in modifying and moving outputs (such as tourists spending and the length of stay). Consequently, the agents involved in the tourism industry should focus on minimizing inputs. However, as Coelli and Perelman (1999) demonstrated, the orientation of the model should not affect the results obtained.
} 
On a theoretical basis, the organizational units (DMUs) participating in the same frontier employ the same set of inputs and share the same technology set. Thus, the DEA discriminatory power is dependent on the homogeneity of the domain of the sample (Samoilenko and Osei-Bryson, 2008). However, as discussed in section 4.2., the Spanish RT have different touristic technologies, management levels, and therefore different production frontiers. To take into account the differences in technology across the Spanish RT, this paper proposes the meta-frontier approach. Based on the metaproduction function introduced by Hayami (1969), and Ruttan and Hayami (1970), this technique aims to provide a homogenous boundary for all heterogeneous DMUs by estimating the frontiers of relatively homogenous groups (Battese and Rao., 2002; Battese et al., 2004; O'Donnell et al., 2008). Finally, a new production frontier (called metatechnology) is obtained through enveloping the boundaries of different groups.

Formally, let $x$ and $y$ denote the (non-negative) input and output vectors of dimensions ( $M \times 1)$ and (Nx1). We assume that production technology is the knowledge and ability to transform inputs into outputs. We consider $K(>1)$ specific technology groups, $T^{K}$. The production technology $\left(T^{k}\right)$ of the $k$ th group, with $k=1,2,3, \ldots K$, is given by:

$$
T^{k}=\left\{\left(x^{k}, y^{k}\right) \in R^{+} \mid x^{k} \text { canproducey } y^{k}\right\}
$$

The production technology set $T^{k}$, provides an equivalent representation of the capability of transforming inputs into outputs. The group-specific input set $\left(X^{k}\right)$ defined for a specific output vector $y^{k}$ is defined as:

$$
X^{k}\left(y^{k}\right)=\left\{x^{k}:\left(x^{k}, y^{k}\right) \in T^{k}\right\}
$$

The boundaries of the input sets determine the 'isoquants'. The group-specific output set $\left(P^{k}\right)$ is defined for a specific vector of input $x^{k}$ as: 
The technology set for the $k$ th group can be represented by the following distance function based on input minimisation:

$$
D_{i}^{k}\left(x^{k}, y^{k}\right)=\sup _{\lambda}\left\{\lambda>0:\left(x^{k} / \lambda\right) \in X^{K}\left(y^{k}\right)\right\}
$$

and it shows the ratio of the actual production levels to the frontier production levels. The distance function can be used to measure the technical efficiency of the production unit (Shepard 1962):

$$
0 \leq T E^{k}\left(x^{k}, y^{k}\right)=\left[D_{i}^{k}\left(x^{k}, y^{k}\right)\right]^{-1} \leq 1
$$

As we assume that there is a sub technology collection $T^{k}$ which operates under a standard technical collection, the production technology of the meta-frontier $\left(T^{\text {meta }}\right)$ is given by:

$$
T^{m e t a}=\left\{T^{1} \cup T^{2} \cup \ldots \cup T^{k}\right\}=\left\{(x, y) \in R^{+} \mid x \text { canproducey }\right\}
$$

Since meta-frontier is different from group frontier, the technical gap between the groups can be overcome, and all the production units have the same technical possibilities to pursuit input minimisation (Battese and Rao, 2002). The input-orientated meta-distance function $\left(D_{i}^{m e t a}\right)$ can be represented as: 


$$
D_{i}^{\text {meta }}(x, y)=\sup _{\lambda}\left\{\lambda>0:(x / \lambda) \in X^{\text {meta }}\left(y^{m e t a}\right)\right\}
$$

Finally, the Technical Efficiency based on the common frontier can be expressed as:

$$
0 \leq T E^{\text {meta }}(x, y)=\left[D_{i}^{\text {meta }}(x, y)\right]^{-1} \leq 1,
$$

From the definition of the metatechnology it can be easily shown that $D_{i}^{k}\left(x^{k}, y^{k}\right) \leq D_{i}^{\text {meta }}$ $(x, y)$.

A purpose of distinguishing the difference between technologies, we define the technology gap ratio (TGR) of efficiency. Following Battese et al. (2004) and O'Donnell et al. (2008), the technology gap ratio (TGR) is constructed as in Eq. (9). The bigger the technology gap ratio, the closer the group frontier technology to the meta-frontier. If $T G R$ equals 1 , no gap exists between the group frontier technology and meta-frontier technology. To illustrate it, the input-orientated TGR can be defined using the input distances functions from technologies $T^{k}$ and $T^{\text {meta }}$ as:

$$
0 \leq T G R_{i}^{k}=\frac{D_{i}^{k}\left(x^{k}, y^{k}\right)}{D_{i}^{\operatorname{meta}}(x, y)}=\frac{T E^{k}\left(x^{k}, y^{k}\right)}{T E^{m e t a}(x, y)} \leq 1
$$

The CCR model fits a linear production technology in the meta-frontier, whereas the BCC model features variable returns to scale, which are more flexible and reflect managerial efficiency as well as purely technical limits.

\section{Parametric regression}

To analyse the extent to which efficiency impact of explanatory factors on Spanish tourist and non-tourist regions, we use the two-stage bootstrap truncated regression procedure (Simar and Wilson, 2007). 
An advantage of the Simar and Wilson (2007) bootstrap procedure is that it allows obtaining unbiased coefficients, valid confidence intervals and describe a data generating process under which two-step methods are consistent. The basic idea of bootstrapping is the recalculation of the parameter of interest. This is achieved by the approximation of the distribution of the estimator via re-sampling. In this research, the recalculated parameter of interest is the DEA efficiency score. Since variables exist to explain the variation in the efficiency scores, the bootstrap procedure can be extended to account for the impact of environmental variables on efficiency (Assaf and Josiassen, 2011). The discriminatory power of the first stage is not affected since the explanatory variables are not included in the first stage (Liebert and Niemeier, 2013).

The mathematical expression of such regression given by:

$$
\varphi_{j}=a+z_{j} \delta+\varepsilon_{j}
$$

Where $a$ is the constant term, $\varepsilon_{j}$ is the error term, $z_{j}$ is a vector (row) of potential covariates that are expected to be related to the DMU's efficiency score, $\varphi$.

\section{The research framework}

The research framework of this study is shown in figure 1. The first stage assesses the efficiency of Spanish regions via DEA (Carner et al., 1978; Banker et al., 1984). The design involves the DEA, which explains technical efficiency (CRS, VRS) and scale efficiency. An advantage of the DEA assessment is that the model can be calculated from different angles and builds a comprehensive analysis with new approaches (Benito et al., 2014). In the second stage, to discover the factors that significantly affect the efficiency in tourist and non-tourist regions in Spain, it applies the bootstrapping method proposed by Simar and Wilson (2007).

The Spanish regions form a quite heterogeneous group in terms of size and output composition. Therefore, changes in the environment or technology could not affect all equally. Consequently, to carry out the analysis, regions are grouped by similar 
characteristic. In this sense, the National Geographical Institute of Spain classifies them in two groups according to their tourism orientation (Fernandez et al. 2018). Group 1 contains regions with the high-density touristic areas (Balears Illes, Canarias, Comunitat Valenciana, Cataluna, Madrid, Murcia, Andalucia) and group 2, regions that do not specialize in tourism (Pais Vasco, Cantabria, Asturias, Aragon, Galicia, Rioja, Castilla Leon, Navarra, Castilla - La Mancha, Extremadura). Figure 1 shows the research framework for this study.

Figure 1: Framework of this study.

\section{Sources and Data}

To evaluate the RT in Spain, the data for 17 Spanish regions (Ceuta and Melilla are not included) have been collected for the period 2008-2018. For the construction of the input and output variables of the determinants of efficiency, data of the National Statistical Institute (INE) and State Meteorological Agency (AEMET) has been used².

Tourism is a type of multi-product process. Numerous variables are of interest for the analysis of the tourist efficiency and productivity of a region. These variables are usually related to accommodation capacity and employment as inputs and, the length of stay (bed-nights) and tourist spending as outputs (Fuchs, 2004; Cracolici et al., 2007; Botti et al., 2009; Barros et al., 2011; Assaf and Josiassen, 2012; Assaf and Tsionas, 2015; Cuccia et al., 2016). However, the identification of inputs and outputs in the measure of tourism efficiency is still an open question since there is no consensus on whether "arrivals" should be considered an input or an output. On the one hand, "tourist arrivals" can be understood as a result (output) of the utilization of tourist inputs (Assaf and Josiassen, 2012; Assaf and Tsionas, 2015; Cracolici et al., 2007; Fuchs, 2004). On the other hand, tourism can also be considered as a process in which "arrivals" (input) is

\footnotetext{
2 Tourist Movement on Borders (FRONTUR), Tourism Expenditure Survey (EGATUR), Hotel Occupancy Survey (HOS), Campsite Occupancy Survey (COS), Labour Force Survey (LFS), Survey of domestic tourism, Tourist Accommodation Occupancy Survey covers, Hostel Occupancy Survey
} 
transformed into overnight stay (bed-nights) and tourist spending (Peypoch and Solonandrasana, 2007; Botti et al., 2009; Barros et al., 2011; Cuccia et al., 2016).

In the first stage of the analysis, output and input variables have been chosen based on a review of the literature mentioned in section 2, and the data at our disposal. As input variables, this study includes Tourists arrivals measured by the number of tourists (both domestic and foreign) arriving to the region, Tourism employment measured by the number of employees involved in tourism, and Tourism capacity measured by the number of available bedrooms to receive tourists. As output variables, Tourists spending is measured by the amount of tourists' spending in MLN euros and, Tourist stay is measured by the total number of overnight stays (length of stay) in hosting places. In this work "tourism arrivals" has been considered as an input variable since we consider that it makes a better approximation of the economic returns of tourism.

To measure the effect of explanatory factors on the efficiency on both Spanish tourist and non-tourist regions, variables need to be logically connected to determine the efficiency. As Lew (1987), Leiper (1990), Barros et al., (2011) and Assaf and Josiassen (2012) indicated the variables selected at this stage include tourism attractors that affect the success of its destination. Thus, to analyse the impact of explanatory factors, four variables were used (z-variables): SUN, SAND, NATURAL ATTRACTIONS, and INSECURITY. Table 2. contains the selection, description, antecedents, analysis and expected sings of these variables.

Table 2: Variables for the Simar and Wilson (2007) analysis of determinants.

The descriptive statistics of the variables used are shown in table 3 and 4 .

Table 3: Summary statistics of inputs and outputs

Table 4: Summary statistics of variables in averages by regions for 2008-2018 
Apart from the Canary Islands and Madrid (capital), geographically, all regions are located in the Mediterranean area.

On the other hand, all non-tourist regions are located in the central and northwestern parts of the country. The level of efficiency of non-tourist regions is lower (between 0.46 and 0.69) compared with the tourist regions. The highest efficiency score (score between 0.50 and 0.60 ) among the non-tourist regions belongs to Pais Vasco and Cantabria. The 


\begin{abstract}
lowest efficiency score belongs to Extremadura (under 0.50). All the rest regions (Asturias, Aragon, Galicia, Rioja, Castilla - Leon, Navarra and Castilla - La Mancha) show a score between 0.40 and 0.50 .
\end{abstract}

As it expected, Spain attracts international tourists with its Sun and Sand type tourism (Aguilo et al., 2005). These results are in line with findings of Munoz (2007), which states that international travellers are concentrated in destinations, such as the Balearic Islands, Canary Islands, Andalusia and Catalonia. The results are also concurrent with the research by Herrero-Prieto and Gomez-Vega, 2017, and Fernández et al., 2018 for airports and cultural festivals.

Table 6. displays the measure of the effect of explanatory factors on the efficiency of both Spanish tourist and non-tourist regions. The analysis results show that the SUN factor negatively affects the efficiency of the tourist $(-0.0105$, CRS; $-0.0074, \mathrm{CRS})$ and nontourist regions $(-0.0018$, CRS; -0.0013 , VRS). The results can be explained by Leibenstein (1966) and its X-inefficiency theory on non-allocative form of efficiency. Sunny regions feel more protected against competition due to favorable environmental conditions. Also, Benito et al., (2014), Munoz (2007), Martin et al., (2017), Hein et al., (2009) support the influence of the sun on incoming visitors.

Table 6: Parameter estimates for the Simar-Wilson regression model of tourist and nontourist regions in Spain (2008-2018).

The variable SAND has a positive effect on tourist $(0.0002, \mathrm{CRS})$ and non-tourist $(0.0002$, VRS) regions efficiency. In other words, the longer the beaches, the higher the efficiency level of the region. The results are consistent with Benito et al., (2014), who found that nature and beaches have a positive effect on the competitiveness of Spanish autonomous communities. Furthermore, seaside and beaches argue by Barros et al., (2011), SellersRubio and Casado-Díaz (2018), Claver-Cortés et al., (2007). 


\begin{abstract}
The explanatory factor NATURAL ATTRACTIONS has a significant positive effect on efficiency in non-tourist regions $(0.0414, \mathrm{CRS})$. This effect may be associated with the attractors of these regions. It is essential to have national parks, as most non-tourist regions regarding their geographical and natural environment have no specific attractors as in tourist regions. These results are consistent with those obtained by Cuccia et al.
\end{abstract} (2017).

Security is an important driver of tourism performance. The explanatory factor INSECURITY has a significant adverse effect on the efficiency of tourist regions (-8.4200, CRS; -1.5500, VRS). The results are in line with Pizam, (1999), Levantis and Gani, (2000), and Santana-Gallego et al., 2016, who too have considered tourist security.

Table 7 shows Technical efficiency $\left(T E^{k}\right)$, Metafrontier efficiency (TE $\left.E^{\text {meta }}\right)$, and technological gaps (TGR), as indicated in section 4.3. In average, the tourist regions possess the best tourism utilisation technology. The results suggest that they require a smaller amount of input to produce a given set of outputs compared to the non-tourist areas.

Table 7: Technical efficiency $\left(T E^{k}\right)$, Metafrontier efficiency $\left(T E^{\text {meta }}\right)$ and technological gaps (TGR)

There are significant differences in efficiency between the tourist and non-tourist Spanish regions over the last 10 years. Figure 3. shows the average ratio of the technological gap in the tourist and non-tourist regions of Spain for the period 2008 - 2018.

Figure 3: Evolution of Technology Gap Ratio (TGR) by groups (2008-2018). 
As the figure illustrates, tourist regions remain on the meta-frontier throughout the entire period $(T G R=1)$. However, there is a convergence between the tourist and non-tourist regions of Spain.

Non-tourism regions show improvements in their level of efficiency. A visible leap in efficiency gains of non-tourist areas has been seen in 2014 and 2016.

\section{Conclusion}

This article aims to assess the drivers of tourism performance of Spain at the regional level. A Meta-frontier DEA (Carnes et al., 1978; Battese et al., 2004; O'Donnell et al., 2008) was first carried out to obtain the efficiency scores for each region. Secondly, the bootstrapping method (Simar and Wilson, 2007) was applied to measure the impact of explanatory factors on tourist and non-tourist regional efficiency. The following novelties are presented in this study: (1) we take into account the heterogeneity of regions in the DEA estimation. Therefore the efficiency evaluation is carried out separately by grouping the regions by their focus on tourism. (2) We evaluate the factors determining performance depending on the tourist orientation of the regions. The first stage of the analysis shows that geographical location has a significant impact on the efficiency of Spanish RT. The most efficient regions are the capital and the tourist-oriented regions with an exit to the seaside.

Over the past 10 years a convergence in the efficiency level between the tourist and nontourist regions of Spain has been observed. On the whole, tourist regions have the best tourism technology. This result indicates that they need fewer resources to get a given set of outputs.

The analysis of the efficiency effect on RT of the second stage showed that the NATURAL ATTRACTIONS impacts positively on tourism performance of the non-tourist regions and the SAND ( $\mathrm{km}$ of beaches) positively affect the efficiency levels of both tourist and nontourist regions. 
The drivers of tourism performance, such as the SUN and INSECURITY harm the efficiency of Spanish RT. The SUN factor negatively affects the efficiency of both tourist and non-tourist regions. A possible explanation for these finding may relate to $\mathrm{X}$ inefficiency theory on the non-allocative form of efficiency by Leibenstein (1966). Regions with more number of sunny days feel more protected against competition due to the favourable environmental conditions and a large number of inbound tourists. The INSECURITY factor also negatively effects the efficiency of tourist regions.

A purpose of these studies is to inform policymakers and tourism managers on the design and implementation of appropriate instruments for enhancing the performance of the tourism industry. Our empirical results describe the efficiency of the sector in Spain and are relevant to establish what factors are significant in the performance of Spanish RT. This research is relevant regarding the importance of security in tourism. For many years, the Spanish tourism model has based its success on the sun and sand factors. However, in recent years the competition of international tourist destinations specialized in the sun and sand model has increased. In this new scenario, security seems to be a determining factor in the success of a tourist destination. Furthermore, natural attractions seem to be a driving force for increasing the tourism efficiency of regions that were not traditionally specialized in tourism.

The above results are meaningful to policymakers. From the results obtained, it can be concluded that a favorable climate is not in itself a guarantee of tourism. Regions traditionally specialized in tourism should try to adapt their tourism model to a new context where security and nature are crucial factors. From this point of view, the results of the study can, above all, be considered as an essential guide for regional authorities to maximise the use of geographical and natural advantages to attract tourists as a source of economic development.

Our findings are also useful for both scientists and practitioners who seek to understand the relationship between tourism and efficiency. This paper contributes to the understanding of the efficiency in tourism in two aspects: First, by demonstrating the importance of heterogeneity in the study of tourism efficiency in territories. Second, by 
delving into the factors that determine tourism efficiency. However, there are limitations to this research. This paper focuses only on the Spanish case and results may not be generalizable. Although we found a direct relationship between the level of security and tourism efficiency, future research could be applied to other international tourist destinations. Additionally, future research could be applied to the comparison of countries rather than regions. 


\section{References}

Abad, A., \& Kongmanwatana, P. (2015). Comparison of destination competitiveness ranking in the European Union using a nonparametric approach. Tourism Economics, 21(2), 267-281.

Aguiló, E., Alegre, J., \& Sard, M. (2005). The persistence of the sun and sand tourism model. Tourism management, 26(2), 219-231.

Aigner, D., Lovell, C. K., \& Schmidt, P. (1977). Formulation and estimation of stochastic frontier production function models. Journal of econometrics, 6(1), 21-37.

Akama, J. S., \& Kieti, D. M. (2003). Measuring tourist satisfaction with Kenya's wildlife safari: a case study of Tsavo West National Park. Tourism management, 24(1), 73-81.

Alberca, P., \& Parte, L. (2018). Operational efficiency evaluation of restaurant firms. International Journal of Contemporary Hospitality Management, 30(3), 1959-1977.

Alegre, J., \& Cladera, M. (2006). Repeat visitation in mature sun and sand holiday destinations. Journal of travel research, 44(3), 288-297.

Assaf, A. G., \& Dwyer, L. (2013). Benchmarking international tourism destinations. Tourism Economics, 19(6), 1233-1247.

Assaf, A. G., \& Josiassen, A. (2011). The operational performance of UK airlines: 20022007. Journal of Economic Studies, 38(1), 5-16.

Assaf, A. G., \& Josiassen, A. (2012). Identifying and Ranking the Determinants of Tourism Performance: A Global Investigation. Journal of Travel Research, 51(4), 388-399. 


\begin{abstract}
Assaf, A. G., \& Josiassen, A. (2016). Frontier analysis: A state-of-the-art review and meta-
\end{abstract} analysis. Journal of Travel Research, 55(5), 612-627.

Assaf, A. G., \& Tsionas, E. G. (2015). Incorporating destination quality into the measurement of tourism performance: A Bayesian approach. Tourism Management, 49, 58-71.

Assaf, A., \& Matawie, K. M. (2008). Cost efficiency modeling in health care foodservice operations. International Journal of Hospitality Management, 27(4), 604-613.

Assaf, A., \& Matawie, K. M. (2010). A bootstrapped metafrontier model. Applied Economics Letters, 17(6), 613-617.

Banker, R. D., Charnes, A., \& Cooper, W. W. (1984). Some models for estimating technical and scale inefficiencies in data envelopment analysis. Management science, 30(9), 1078-1092.

Barros, C. P., Botti, L., Peypoch, N., Robinot, E., \& Solonandrasana, B. (2011). Performance of French destinations: Tourism attraction perspectives. Tourism Management, 32(1), 141-146.

Battese, G. E., \& Rao, D. P. (2002). Technology gap, efficiency, and a stochastic metafrontier function. International Journal of Business and Economics, 1(2), 87.

Battese, G. E., Rao, D. P., \& O'donnell, C. J. (2004). A Meta-frontier production function for estimation of technical efficiencies and technology gaps for firms operating under different technologies. Journal of productivity analysis, 21(1), 91-103.

Benito, B., Solana, J., \& López, P. (2014). Determinants of Spanish regions' tourism performance: a two-stage, double-bootstrap data envelopment analysis. Tourism Economics, 20(5), 987-1012. 


\begin{abstract}
Bosetti, V., Cassinelli, M., \& Lanza, A. (2004). Using Data Envelopment Analysis to
\end{abstract} Evaluate Environmentally Conscious Tourism Management.

Bosetti, V., Cassinelli, M., \& Lanza, A. (2007). Benchmarking in Tourism Destinations; Keeping in Mind the Sustainable Paradigm. Advances in Modern Tourism Research, 165180.

Botti, L., Peypoch, N., Robinot, E., \& Solonadrasana, B. (2009). Tourism destination competitiveness: the french regions case. European Journal of Tourism Research, 2(1), $5-24$.

Buultjens, J., \& Luckie, K. (2004). Economic impact of selected national parks in northeastern New South Wales. Gold Coast: CRC for Sustainable Tourism.

Charnes, A., Cooper, W. W., \& Rhodes, E. (1978). Measuring the efficiency of decision making units. European journal of operational research, 2(6), 429-444.

Chen, Y. H., Lai, P. L., \& Piboonrungroj, P. (2017). The relationship between airport performance and privatisation policy: A nonparametric metafrontier approach. Journal of Transport Geography, 62, 229-235.

Chiu, C. R., Chiu, Y. H., Chen, Y. C., \& Fang, C. L. (2016). Exploring the source of metafrontier inefficiency for various bank types in the two-stage network system with undesirable output. Pacific-Basin Finance Journal, 36, 1-13.

Chiu, C. R., Lu, K. H., Tsang, S. S., \& Chen, Y. F. (2013). Decomposition of meta-frontier inefficiency in the two-stage network directional distance function with quasi-fixed inputs. International Transactions in Operational Research, 20(4), 595-611. 
Chiu, Y. H., Luo, Z., Chen, Y. C., Wang, Z., \& Tsai, M. P. (2013). A comparison of operating performance management between Taiwan banks and foreign banks based on the Meta-Hybrid DEA model. Economic Modelling, 33, 433-439.

Cho, T. Y., \& Wang, T. Y. (2018). Estimations of cost metafrontier Malmquist productivity index: using international tourism hotels in Taiwan as an example. Empirical Economics, 55(4), 1661-1694.

Claver-Cortés, E., Molina-Azorı, J. F., \& Pereira-Moliner, J. (2007). Competitiveness in mass tourism. Annals of tourism Research, 34(3), 727-745.

Coelli, T., \& Perelman, S. (1999). A comparison of parametric and non-parametric distance functions: With application to European railways. European journal of operational research, 117(2), 326-339.

Coelli, T. J., Rao, D. S. P., O'Donnell, C. J., \& Battese, G. E. (2005). An introduction to efficiency and productivity analysis. Springer Science \& Business Media.

Cracolici, M. F., Nijkamp, P., \& Cuffaro, M. (2007). Efficiency and productivity of Italian tourist destinations: a quantitative estimation based on data envelopment analysis and the Malmquist method. In Advances in modern tourism research (pp. 325-343). PhysicaVerlag HD.

Cuccia, T., Guccio, C., \& Rizzo, I. (2016). The effects of UNESCO World Heritage List inscription on tourism destinations performance in Italian regions. Economic Modelling, 53, 494-508.

Cuccia, T., Guccio, C., \& Rizzo, I. (2017). UNESCO sites and performance trend of Italian regional tourism destinations: $A$ two-stage DEA window analysis with spatial interaction. Tourism Economics, 23(2), 316-342. 
Fang, C. Y., \& Hsu, F. S. (2012). Meal category analysis: An application of the metafrontier approach. Tourism Economics, 18(5), 1083-1095.

Fang, C. Y., \& Hsu, F. S. (2014). An efficiency-based metafrontier approach to menu analysis. Journal of Hospitality \& Tourism Research, 38(2), 199-221.

Fang, C. Y., Peng, P. Y., \& Pan, W. T. (2013). Does using an à la carte or combo set menu affect the performance of a teppanyaki-style restaurant?. International Journal of Contemporary Hospitality Management, 25(4), 491-509.

Färe, R., \& Grosskopf, S. (2010). Directional distance functions and slacks-based measures of efficiency. European journal of operational research, 200(1), 320-322.

Farrell, M. J. (1957). The measurement of productive efficiency. Journal of the Royal Statistical Society: Series A (General), 120(3), 253-281.

Fernández, X. L., Coto-Millán, P., \& Díaz-Medina, B. (2018). The impact of tourism on airport efficiency: The Spanish case. Utilities Policy, 55, 52-58.

Fuchs, M. (2004). Strategy development in tourism destinations: a DEA approach. Poznan University Economics Review, 4(1), 52-73.

George, R. (2003). Tourist's perceptions of safety and security while visiting Cape Town. Tourism Management, 24(5), 575-585.

Gisbert, J. I., Palazón, A., López, I., Aragonés, I., \& Villacampa, Y. (2018). Study of the relationship between the number of travelers and beach services in Spain. WIT Transactions on Ecology and the Environment, 227, 43-51.

Gómez-Martín, M. B. (2006). Climate potential and tourist demand in Catalonia (Spain) during the summer season. Climate Research, 32(1), 75-87. 
Hadad, S., Hadad, Y., Malul, M., \& Rosenboim, M. (2012). The economic efficiency of the tourism industry: a global comparison. Tourism economics, 18(5), 931-940.

Harper Jr, D. W. (2001). Comparing tourists crime victimization. Annals of Tourism Research, 28(4), 1053-1056.

Hayami, Y. (1969). Sources of agricultural productivity gap among selected countries. American Journal of Agricultural Economics, 51(3), 564-575.

Hein, L., Metzger, M. J., \& Moreno, A. (2009). Potential impacts of climate change on tourism; a case study for Spain. Current Opinion in Environmental Sustainability, 1(2), 170-178.

Herrero-Prieto, L. C., \& Gomez-Vega, M. (2017). Cultural resources as a factor in cultural tourism attraction: Technical efficiency estimation of regional destinations in Spain. Tourism Economics, 23(2), 260-280.

Huang, C. W., Ting, C. T., Lin, C. H., \& Lin, C. T. (2013). Measuring non-convex metafrontier efficiency in international tourist hotels. Journal of the Operational Research Society, 64(2), 250-259.

Lam, S. W., Low, J. M., \& Tang, L. C. (2009). Operational efficiencies across Asia Pacific airports. Transportation Research Part E: Logistics and Transportation Review, 45(4), 654-665.

Leibenstein, H. (1966). Allocative efficiency vs." X-efficiency". The American Economic Review, 56(3), 392-415.

Leiper, N. (1990). Tourist attraction systems. Annals of tourism research, 17(3), 367-384. 
Levantis, T., \& Gani, A. (2000). Tourism demand and the nuisance of crime. International Journal of Social Economics, 27(7/8/9/10), 959-967.

Lew, A. A. (1987). A framework of tourist attraction research. Annals of tourism research, 14(4), 553-575.

Liebert, V., \& Niemeier, H. M. (2013). A survey of empirical research on the productivity and efficiency measurement of airports. Journal of Transport Economics and Policy (JTEP), 47(2), 157-189.

Lin, C. H., Chiu, Y. H., \& Huang, C. W. (2012). Assessment of technology gaps of tourist hotels in productive and service processes. The Service Industries Journal, 32(14), 23292342 .

Lozano, S., \& Gutiérrez, E. (2011). Efficiency analysis of EU-25 member states as tourist destinations. International Journal of Services Technology and Management, 15(1-2), 6988.

Lu, Y. H., \& Chen, C. F. (2012). Research note: Analysing the efficiency of the Taiwanese hotel industry: a stochastic metafrontier approach. Tourism Economics, 18(5), 11431150.

Martin, J. C., Mendoza, C., \& Roman, C. (2017). Regional Spanish Tourism Competitiveness. A DEA-MONITUR approach. Region, 4(3), 153-173.

Mayer, M., Müller, M., Woltering, M., Arnegger, J., \& Job, H. (2010). The economic impact of tourism in six German national parks. Landscape and Urban Planning, 97(2), 73-82.

Medal-Bartual, A., Garcia-Martin, C. J., \& Sala-Garrido, R. (2012). Efficiency analysis of small franchise enterprises through a DEA metafrontier model. The Service Industries Journal, 32(15), 2421-2434. 
Mei, G., Gan, J., \& Zhang, N. (2015). Metafrontier environmental efficiency for China's regions: A slack-based efficiency measure. Sustainability, 7(4), 4004-4021.

Molinos-Senante, M., Maziotis, A., \& Sala-Garrido, R. (2015). Assessing the relative efficiency of water companies in the English and welsh water industry: a metafrontier approach. Environmental Science and Pollution Research, 22(21), 16987-16996.

Munoz, T. G. (2007). German demand for tourism in Spain. Tourism Management, 28(1), $12-22$.

National Statistical Institute. https://www.ine.es

New, M., Lister, D., Hulme, M., \& Makin, I. (2002). A high-resolution data set of surface climate over global land areas. Climate research, 21(1), 1-25.

O'Donnell, C. J., Rao, D. P., \& Battese, G. E. (2008). Meta-frontier frameworks for the study of firm-level efficiencies and technology ratios. Empirical economics, 34(2), 231255.

Pendleton, L., King, P., Mohn, C., Webster, D. G., Vaughn, R., \& Adams, P. N. (2011). Estimating the potential economic impacts of climate change on Southern California beaches. Climatic Change, 109(1), 277-298.

Peypoch, N. (2007). On measuring tourism productivity. Asia Pacific Journal of Tourism Research, 12(3), 237-244.

Peypoch, N., \& Solonandrasana, B. (2007). On "E-Attraction" Tourism Destination" Extension and Application. In Advances in modern tourism research (pp. 293-306). Physica-Verlag HD. 
Pizam, A. (1999). A comprehensive approach to classifying acts of crime and violence at tourism destinations. Journal of travel research, 38(1), 5-12.

Ruttan, V. W., \& Hayami, Y. (1970). Agricultural Productivity Differences Across Countries. American Economic Review, 60, 895-911.

Sala-Garrido, R., Molinos-Senante, M., \& Hernández-Sancho, F. (2011). Comparing the efficiency of wastewater treatment technologies through a DEA metafrontier model. Chemical Engineering Journal, 173(3), 766-772.

Samoilenko, S., \& Osei-Bryson, K. M. (2008). Increasing the discriminatory power of DEA in the presence of the sample heterogeneity with cluster analysis and decision trees. Expert Systems with Applications, 34(2), 1568-1581.

Santana-Gallego, M., RossellÃ-Nadal, J., \& Fourie, J. (2016). The effects of terrorism, crime and corruption on tourism. Economic Research Southern Africa (ERSA), 595, 1-28.

Sellers-Rubio, R., \& Casado-Díaz, A. B. (2018). Analyzing hotel efficiency from a regional perspective: The role of environmental determinants. International Journal of Hospitality Management, 75, 75-85.

Shepard, R. N. (1962). The analysis of proximities: Multidimensional scaling with an unknown distance function. Psychometrika (I and 11), 27, 125-139, 219-246.

Simar, L., \& Wilson, P. W. (2007). Estimation and inference in two-stage, semi-parametric models of production processes. Journal of econometrics, 136(1), 31-64.

Soysal-Kurt, H. (2017). Measuring tourism efficiency of European countries by using data envelopment analysis. European Scientific Journal, 13(10), 31-49.

Spanish Ministry for the Ecological Transition. http://www.miteco.gob.es 
State Meteorological Agency. http://www.aemet.es/es/portada

Tiedemann, T., Francksen, T., \& Latacz-Lohmann, U. (2011). Assessing the performance of German Bundesliga football players: a non-parametric metafrontier approach. Central European Journal of Operations Research, 19(4), 571-587.

Tourist Movement on Borders. https://www.ine.es/dyngs/INEbase/es/operacion.htm?c=Estadistica_C\&cid=1254736176 $\underline{996 \& \text { menu }=u l t i D a t o s \& i d p=1254735576863}$

United World Tourism Organization. http://www2.unwto.org

Wang, Q., Zhou, P., Ge, S., \& Zhao, Z. (2014). An International Comparison of Carbon Dioxide Emission Performance Using the Nonparametric Metafrontier Approach. Polish Journal of Environmental Studies, 23(3).

Word Bank. http://data.worldbank.org

World Travel and Tourism Council. https://www.wttc.org

Yu, M. M., \& Chen, L. H. (2019). Evaluation of efficiency and technological bias of tourist hotels by a meta-frontier DEA model. Journal of the Operational Research Society, 1-15.

Yu, Y., Choi, Y., \& Zhang, N. (2015). Strategic corporate sustainability performance of Chinese state-owned listed firms: A meta-frontier generalized directional distance function approach. The Social Science Journal, 52(3), 300-310.

Zha, J., Zhu, Y., He, D., Tan, T., \& Yang, X. (2019). Sources of tourism growth in Mainland China: An extended data envelopment analysis-based decomposition analysis. International Journal of Tourism Research. 
Zhang, N., Zhou, P., \& Choi, Y. (2013). Energy efficiency, CO2 emission performance and technology gaps in fossil fuel electricity generation in Korea: A meta-frontier nonradial directional distance functionanalysis. Energy Policy, 56, 653-662. 
Table 1: DEA oriented Meta-frontier approach timetable

\begin{tabular}{|l|l|l|l|}
\hline$\#$ & Article & Applied method & Year \\
\hline 1 & $\begin{array}{l}\text { Assaf and } \\
\text { Matawie }\end{array}$ & Bootstrapping method & 2010 \\
\hline 2 & $\begin{array}{l}\text { Sala-Garrido et } \\
\text { al. }\end{array}$ & Non-concave Meta-frontier DEA & 2011 \\
\hline 3 & Tiedemann et al. & Non-concave Meta-frontier DEA & 2011 \\
\hline 4 & $\begin{array}{l}\text { Sala Garrido et } \\
\text { al. }\end{array}$ & Ratio form to compute the technology gap & 2011 \\
\hline 5 & Chiu et al. & $\begin{array}{l}\text { Hybrid Meta-frontier DEA to distinguish inputs and } \\
\text { outputs into radial inputs and outputs }\end{array}$ & 2013 \\
\hline 6 & $\begin{array}{l}\text { Chiu et al. } \\
\text { Meta-frontier DEA model based on the two-stage } \\
\text { network directional distance function with quasi-fixed } \\
\text { inputs }\end{array}$ & 2013 \\
\hline 7 & Zhang et al. & Meta-frontier non-radial directional distance function & 2013 \\
\hline 8 & Yu et al. & $\begin{array}{l}\text { Meta-frontier generalised directional distance function } \\
\text { approach from O'Donnell et al. (2008) and Fare and } \\
\text { Grosskopf (2010) }\end{array}$ & 2015 \\
\hline 9 & Mei et al. & Meta-frontier slack-based efficiency measure & 2015 \\
\hline 10 & Chiu et al. & $\begin{array}{l}\text { Meta-frontier DEA model with the two-stage network } \\
\text { directional distance function }\end{array}$ & 2016 \\
\hline
\end{tabular}


Figure 1: Framework of this study.

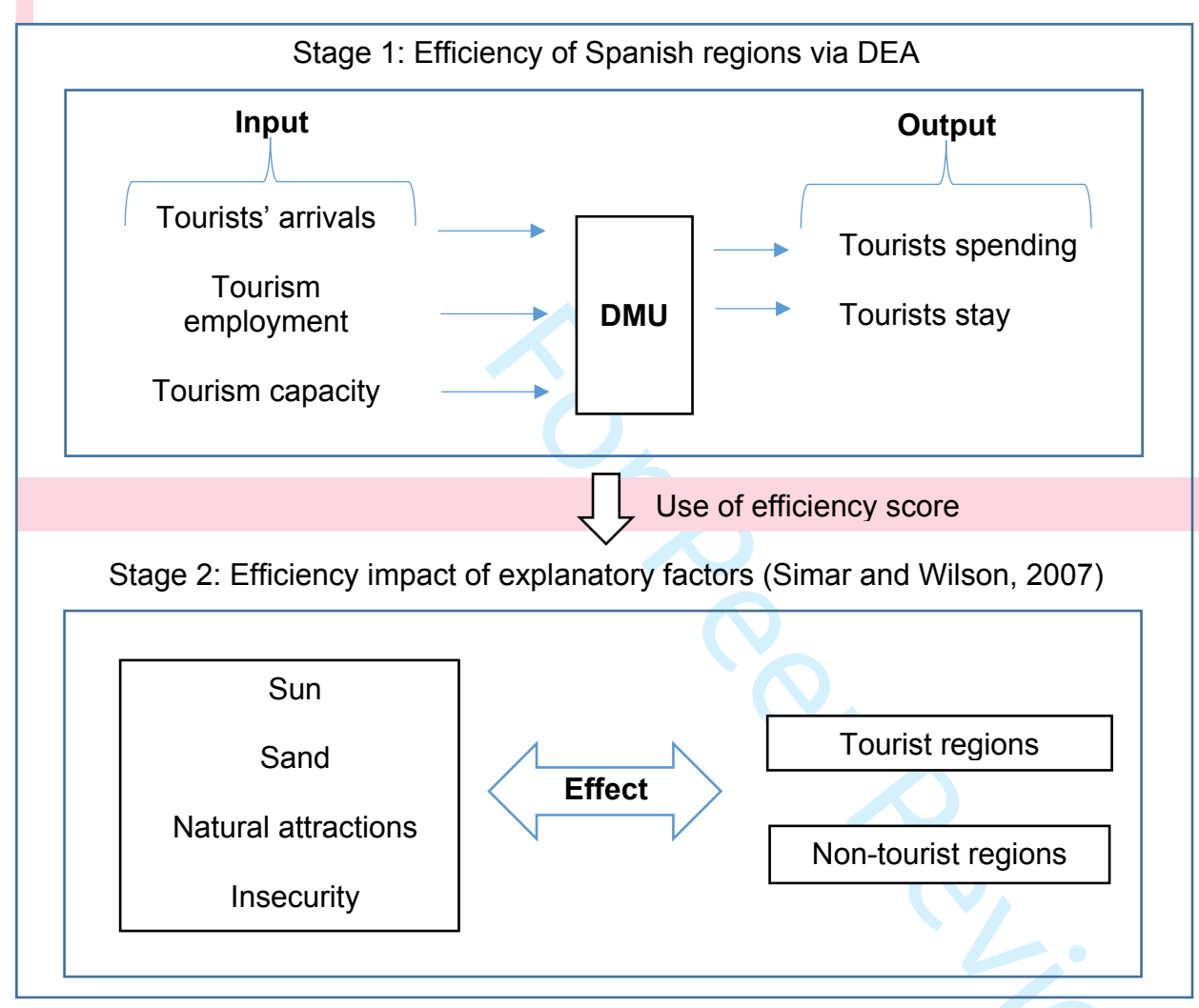


Table 2: Variables for the Simar and Wilson (2007) analysis of determinants.

\begin{tabular}{|c|c|c|}
\hline Factor & Description & $\begin{array}{l}\text { Expected } \\
\text { sing }\end{array}$ \\
\hline SUN & $\begin{array}{l}\text { The destinations climate is one of the main factors } \\
\text { considered by travellers (Hein et al., 2009). Gómez- } \\
\text { Martín (2006) shows that the sun is considered as an } \\
\text { uncontrollable tourism attractor in Spanish destinations. } \\
\text { The total number of hours of sunshine per year (2008- } \\
\text { 2018) has been used as a proxy of the variable. The } \\
\text { data for our analysis has been gathered by the State } \\
\text { Meteorological Agency } \\
\text { http://www.aemet.es/es/portada). }\end{array}$ & Positive \\
\hline SAND & $\begin{array}{l}\text { Beaches are a crucial driver of RT in Spain (Gisbert et } \\
\text { al., 2018). Hence the primary motivation for } 60 \% \text { of the } \\
\text { tourists coming to Spain is to enjoy the sun and beaches } \\
\text { (New et al., 2002). Studies moreover show that the } \\
\text { economic effects of beaches are significant to local } \\
\text { communities (Pendleton et al., 2011). The length of } \\
\text { beaches (km) by region was used as a determining } \\
\text { factor in the analysis. The data has been obtained in the } \\
\text { National Statistical Institute (INE, https://www.ine.es). }\end{array}$ & Positive \\
\hline $\begin{array}{l}\text { NATURAL } \\
\text { ATTRACTIONS }\end{array}$ & $\begin{array}{l}\text { National parks are considered as an uncontrollable } \\
\text { attractor that create considerable income for adjacent } \\
\text { communities and can diversify regional tourism (Mayer } \\
\text { et al., 2010). Besides, national parks have an economic } \\
\text { impact on the regions (Buultjens and Luckie, 2004). } 15 \\
\text { Spanish national parks were used in the analysis. } \\
\text { Variable dummy takes the value } 0 \text { if the region has no } \\
\text { national parks and } 1 \text { if otherwise. Data for these have }\end{array}$ & Positive \\
\hline
\end{tabular}


been obtained in the Spanish Ministry for the Ecological Transition (MITECO, http://www.miteco.gob.es).

\section{INSECURITY}

Security affects tourism demand (Harper 2001; George Negative 2003). Studies on return visits also show that tourists are more likely to be deterred from travelling or returning to dangerous countries or regions in which there are security concerns (Alegre and Cladera, 2006). For example, when the tragic events of September 11th occurred, the image of international tourism was severely damaged, and travellers cancelled their planned trips due to perceived increased risk (Akama and Kieti 2003). The insecurity factor is measured by the number of crimes recorded by the Spanish police department by regions (2008-2018). The data obtained from the National Statistical Institute (INE, https://www.ine.es). 
Table 3: Summary statistics of inputs and outputs

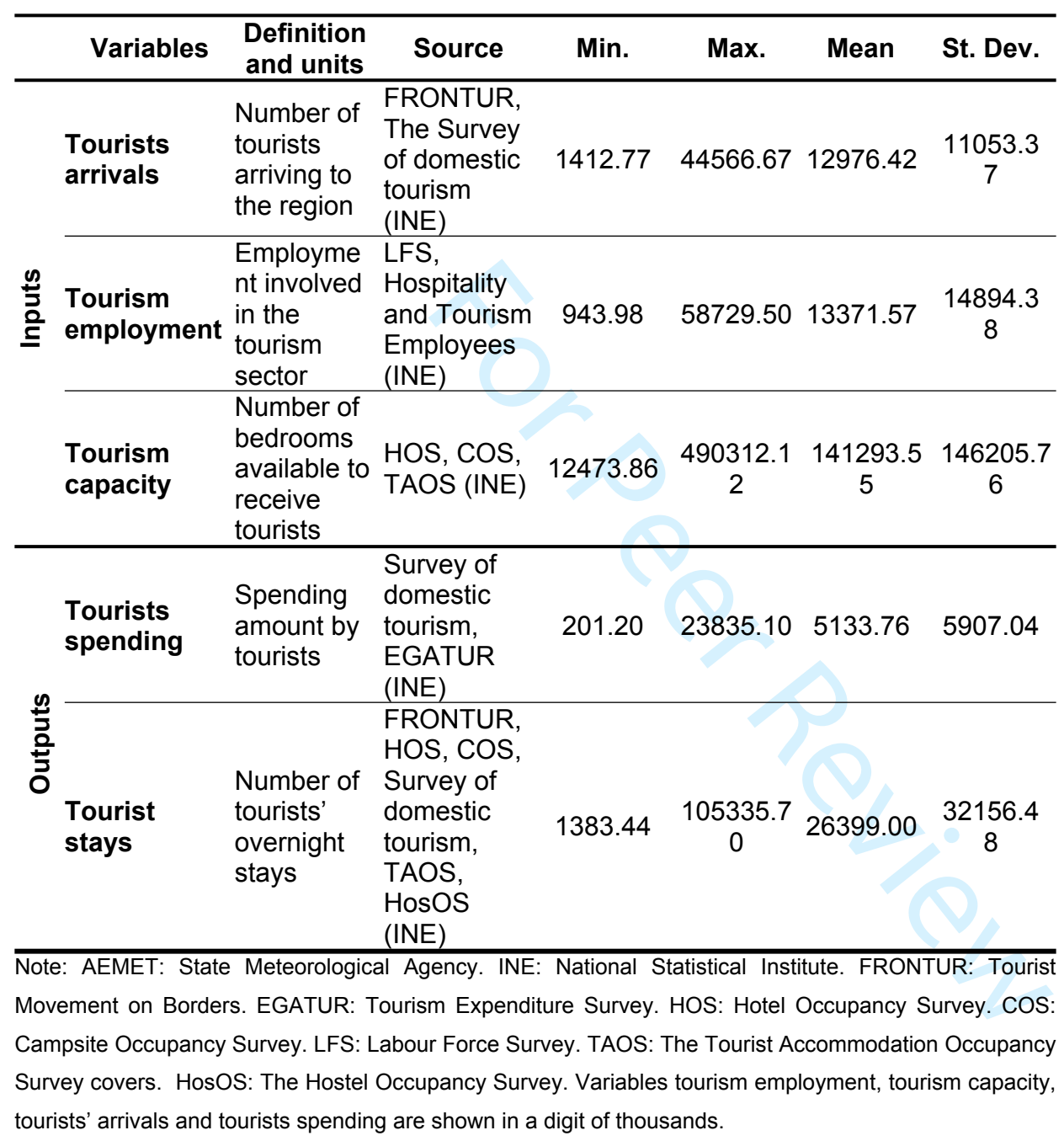


Table 4: Summary statistics of variables by regions (average of 2008-2018)

\begin{tabular}{|c|c|c|c|c|c|}
\hline $\begin{array}{l}\text { Non-tourist } \\
\text { regions }\end{array}$ & $\begin{array}{l}\text { Tourism } \\
\text { capacity }\end{array}$ & $\begin{array}{c}\text { Tourism } \\
\text { employment }\end{array}$ & $\begin{array}{l}\text { Tourists } \\
\text { arrivals }\end{array}$ & $\begin{array}{l}\text { Tourist } \\
\text { stay }\end{array}$ & $\begin{array}{l}\text { Tourists } \\
\text { spending }\end{array}$ \\
\hline Pais Vasco & 39212.66 & 4379.20 & 5226.27 & 6641.20 & 1734.73 \\
\hline Cantabria & 39098.11 & 2560.45 & 3991.07 & 4407.17 & 821.32 \\
\hline Asturias & 40936.12 & 3153.76 & 4759.03 & 4567.84 & 999.69 \\
\hline Aragon & 68330.05 & 4733.31 & 7619.92 & 7243.94 & 1191.14 \\
\hline Galicia & 82459.19 & 7320.15 & 9616.08 & 10404.69 & 1906.79 \\
\hline Rioja & 14238.86 & 1008.39 & 1710.59 & 1466.18 & 247.89 \\
\hline Castilla - Leon & 47878.81 & 3897.47 & 12025.24 & 4348.08 & 1273.46 \\
\hline $\begin{array}{l}\text { Navarra } \\
\text { Castilla - La }\end{array}$ & 24407.12 & 1925.67 & 2914.16 & 2547.95 & 489.87 \\
\hline Mancha & 87457.08 & 7844.95 & 17479.97 & 9356.92 & 2498.78 \\
\hline Extremadura & 28150.52 & 2694.52 & 4967.85 & 2846.58 & 742.34 \\
\hline \multicolumn{6}{|l|}{ Tourist regions } \\
\hline Balears Illes & 236510.46 & 30446.66 & 14178.27 & 73719.68 & 11692.19 \\
\hline $\begin{array}{l}\text { Canarias } \\
\text { Comunitat }\end{array}$ & 395995.67 & 50444.42 & 16292.57 & 101545.83 & 13473.15 \\
\hline Valenciana & 280334.90 & 18141.28 & 23560.24 & 45169.85 & 8903.85 \\
\hline Cataluna & 467683.63 & 34089.75 & 38244.43 & 79574.13 & 17599.41 \\
\hline Madrid & 129798.27 & 15246.02 & 16269.45 & 25413.53 & 8140.63 \\
\hline Murcia & 40939.13 & 2724.84 & 4344.06 & 5167.97 & 1158.15 \\
\hline Andalucia & 378559.77 & 36705.80 & 37399.89 & 64361.52 & 14400.54 \\
\hline
\end{tabular}

Note: Variables tourism employment, tourism capacity, tourists' arrivals, tourists spending and population are shown in digit of thousands. 
Table 5: The average scores of efficiency of tourist and non-tourist regions in Spain (20082018) ranked overall technical efficiency (CRS), pure technical efficiency (VRS) and scale efficiency.

\begin{tabular}{llll}
\hline Region & $\begin{array}{c}\text { Overall } \\
\text { technical } \\
\text { efficiency } \\
\text { (CRS) }\end{array}$ & $\begin{array}{c}\text { Pure technical } \\
\text { efficiency (VRS) }\end{array}$ & $\begin{array}{c}\text { Scale } \\
\text { efficiency }\end{array}$ \\
\hline Non-tourist regions & 0.69 & 0.83 & 0.82 \\
\hline Pais Vasco & 0.66 & 0.80 & 0.82 \\
\hline Cantabria & 0.58 & 0.69 & 0.84 \\
\hline Asturias & 0.58 & 0.65 & 0.88 \\
\hline Aragon & 0.56 & 0.60 & 0.93 \\
\hline Galicia & 0.55 & 1.00 & 0.55 \\
\hline Rioja & 0.52 & 0.56 & 0.94 \\
\hline Castilla - Leon & 0.51 & 0.74 & 0.69 \\
\hline Navarra & 0.51 & 0.60 & 0.84 \\
\hline Castilla - La Mancha & 0.46 & 0.68 & 0.69 \\
\hline Extremadura & $\mathbf{0 . 5 6}$ & $\mathbf{0 . 7 2}$ & \\
\hline Average & & & 1.00 \\
\hline Tourist regions & & & 0.99 \\
\hline Balears Illes & 1.00 & 1.00 & 1.00 \\
\hline Canarias & 0.99 & 1.00 & 0.98 \\
\hline Comunitat Valenciana & 0.96 & 0.96 & 0.98 \\
\hline Cataluna & 0.94 & 0.97 & 0.87 \\
\hline Madrid & 0.85 & 0.87 & 0.97 \\
\hline Murcia & 0.77 & 0.88 & $\mathbf{0 . 8 7}$ \\
\hline Andalucia & 0.73 & 0.75 & $\mathbf{0 . 9 2}$ \\
\hline Average & $\mathbf{0 . 8 9}$ & $\mathbf{0 . 8 0}$ & \\
\hline Average in total & $\mathbf{0 . 7 0}$ & & \\
\hline SObRcE: Sef-elabota & & \\
\hline
\end{tabular}




\section{Table 6: Parameter estimates for the Simar-Wilson regression model of tourist and} non-tourist regions in Spain (2008-2018).

\begin{tabular}{|c|c|c|c|c|c|}
\hline \multirow[b]{2}{*}{$\begin{array}{l}\text { Explanatory } \\
\text { factors }\end{array}$} & \multicolumn{2}{|c|}{$\begin{array}{l}\text { Overall technical } \\
\text { efficiency -CRS- (z- } \\
\text { statistic) }\end{array}$} & \multicolumn{2}{|c|}{$\begin{array}{l}\text { Pure technical efficiency } \\
\text {-VRS- (z-statistic) }\end{array}$} & \multirow{2}{*}{ Expected } \\
\hline & $\begin{array}{l}\text { Tourist } \\
\text { regions }\end{array}$ & $\begin{array}{l}\text { Non-tourist } \\
\text { regions }\end{array}$ & $\begin{array}{l}\text { Tourist } \\
\text { regions }\end{array}$ & $\begin{array}{c}\text { Non-tourist } \\
\text { regions }\end{array}$ & \\
\hline SUN & $\begin{array}{c}-0.0105^{\star *} \\
(-2.41)\end{array}$ & $\begin{array}{c}-0.0018^{\star \star *} \\
(-6.22)\end{array}$ & $\begin{array}{c}-0.0074^{* \star *} \\
(-3.64)\end{array}$ & $\begin{array}{c}-0.0013^{* *} \\
(-2.18)\end{array}$ & Positive \\
\hline SAND & $\begin{array}{c}0.0002^{*} \\
(1.83)\end{array}$ & $\begin{array}{l}0.0000 \\
(0.98)\end{array}$ & $\begin{array}{c}-0.0002 \\
(-0.49)\end{array}$ & $\begin{array}{c}0.0002^{*} \\
(1.79)\end{array}$ & Positive \\
\hline $\begin{array}{c}\text { NATURAL } \\
\text { ATTRACTIONS }\end{array}$ & $\begin{array}{c}0.0998 \\
(0.87)\end{array}$ & $\begin{array}{c}0.0414^{* *} \\
(2.08)\end{array}$ & $\begin{array}{l}-0.0162 \\
(-0.17)\end{array}$ & $\begin{array}{c}0.0095 \\
(0.26)\end{array}$ & Positive \\
\hline INSECURITY & $\begin{array}{c}-8.4200^{*} \\
(-1.84)\end{array}$ & $\begin{array}{c}-1.3200 \\
(-0.41)\end{array}$ & $\begin{array}{c}-1.5500^{* * *} \\
(-3.42)\end{array}$ & $\begin{array}{c}-4.4100 \\
(-0.69)\end{array}$ & Negative \\
\hline
\end{tabular}

Notes: ${ }^{* *},{ }^{* *}$, and ${ }^{*}$ : Below the $1 \%, 5 \%$ and $10 \%$ statistical significance thresholds, respectively. Likelihood ratio chi-square $(\mathrm{df}=2)$ 
Table 7: Technical efficiency $\left(\boldsymbol{T} \boldsymbol{E}^{\boldsymbol{k}}\right)$, Metafrontier efficiency $\left(\boldsymbol{T} \boldsymbol{E}^{\boldsymbol{m e t a}}\right)$ and technological gaps (TGR)

\begin{tabular}{lrr}
\hline \multicolumn{1}{c}{ Criteria } & Average & \multicolumn{1}{c}{ Std. Dev. } \\
\hline All regions & Average & Std. Dev. \\
\cline { 2 - 4 } Technical efficiency & 0.84 & 0.12 \\
\hline Metafrontier efficiency & 0.70 & 0.19 \\
\hline Technology Gap Ratio & 0.82 & 0.15 \\
\hline
\end{tabular}

\begin{tabular}{|c|c|c|c|}
\hline Tourist regions & 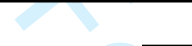 & Average & Std. Dev. \\
\hline Technical efficiency & & 0.89 & 0.12 \\
\hline Metafrontier efficiency & +2 & 0.89 & 0.12 \\
\hline Technology Gap Ratio & +2 & 1.00 & 0.00 \\
\hline
\end{tabular}

\begin{tabular}{|c|c|c|}
\hline Non-tourist regions & Average & Std. Dev. \\
\hline Technical efficiency & 0.70 & 0.12 \\
\hline Metafrontier efficiency & 0.56 & 0.08 \\
\hline Technology Gap Ratio & 0.70 & 0.06 \\
\hline
\end{tabular}

Figure 2: Tourism efficiency in Spain

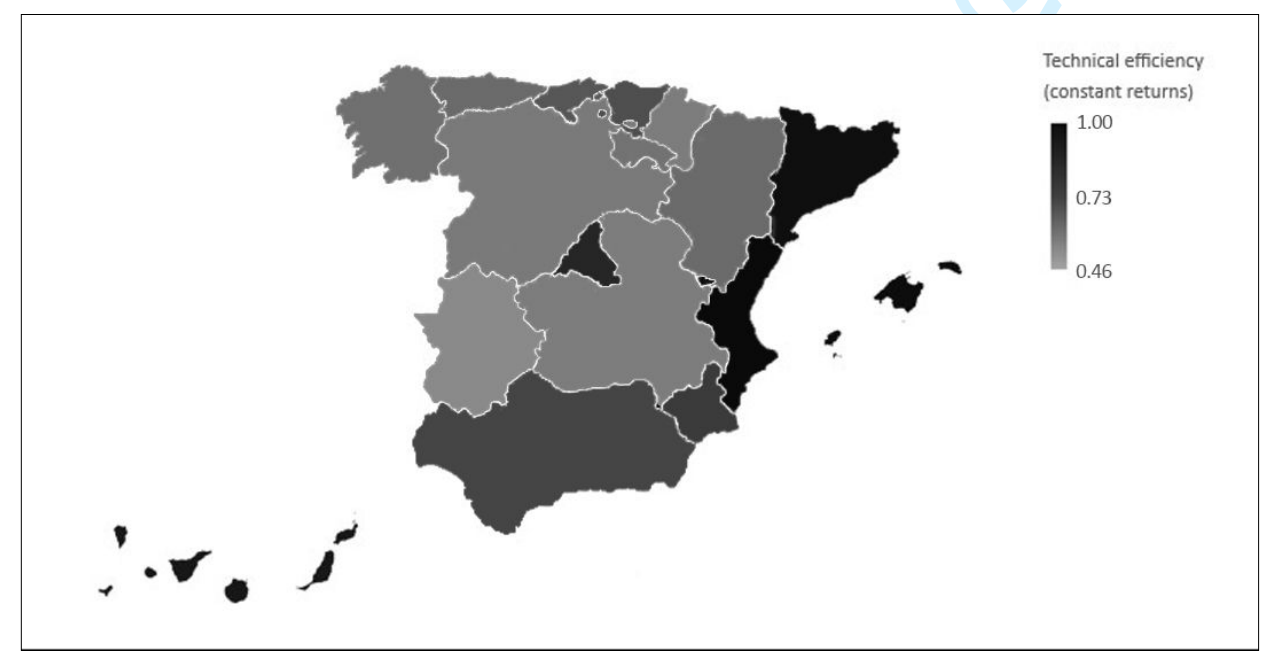


Figure 3: Evolution of Technology Gap Ratio (TGR) by groups (2008-2018). 